\author{
JAKUB CHACHULSKI
}

INSTYTUT SZTUKI, POLSKA AKADEMIA NAUK

\title{
„ZŁY SMAK I GMINNA PRZESADA”. \\ KILKA UWAG O MUZYCZNO-DRAMATYCZNEJ KONSTRUKCJI OPERY SUETAN WAMPUM JÓZEFA ELSNERA NA TLE ORYGINALNEGO LIBRETTA AUGUSTA VON KOTZEBUE
}

$8_{\mathrm{d}}^{\mathrm{n}}$ maja i8or r. na scenie teatru w Warszawie debiutował jako dramatopisarz dwudziestoczteroletni Ludwik Adam Dmuszewski, przyszły pierwszy amant warszawskiej sceny i współdyrektor teatru, od roku już znany nadwiślańskiej publiczności jako aktor i tłumacz. Wystawianą komedią Aktorowie na Elizejskich Polach podejmował młody autor próbę ujęcia w literacką całość popularnej podówczas praktyki spektaklu „quod libet” - teatralnego potpourri złożonego z najpopularniejszych scen wybranych z całorocznego repertuaru. Nad Styks sprowadził więc kolejno Dmuszewski najbardziej charakterystyczne postaci występujące w cieszących się powodzeniem produkcjach warszawskiej sceny, bez skrupułów mieszając charaktery tragiczne z komicznymi, nie omijając także i opery. Pośród nich pojawia się perski sułtan, który zwraca się do Charona i innych obecnych już na scenie postaci następującymi słowy:

Hola! Zaraz mi cicho, nikczemne robaki,

Cicho głowy baranie - jako? Któż to taki,

Śmie wprzódy niżeli ja umieścić się w raju,

(do Charona)

Słuchaj no, ty brodaczu, ty stary hultaju,

I O komedii Dmuszewskiego zob.: Stefan Durski, Dramatopisarstwo Ludwika Adama Dmuszewskiego, Wrocław 1968, s. 3I-42. Jak podaje Kazimierz Władysław Wóycicki (tegoż, Cmentarz Powązowski pod Warszawą, Warszawa I855, s. 200), przy okazji imienin Bogusławskiego w I803 r. sztukę wystawiono z dodatkiem piosenek dopisanych przez Elsnera (informację tę powtarza Alina Nowak Romanowicz, Józef Elsner, Kraków 1957, s. 289). Świadczyłoby to o tym, że wodewilową współpracę z Dmuszewskim rozpoczął kompozytor jeszcze przed komediooperą Siedem razy jeden. Piosenki musiały być ściśle związane z okolicznościami tego wystawienia, skoro nie drukowano ich w żadnym z późniejszych wydań komedii. 
Jeśli ja pierwszy w twą łódź nie będę przyjęty,

Każę ci sto wyliczyć na brzuch albo w pięty².

Wydając komedię drukiem rok później (I802), nie omieszka Dmuszewski wyjaśnić w przypisie pochodzenia postaci wschodniego władcy:

Suttan Wampum, opera Kotzebuego, z muzyką Józefa Elsnera, dyrektora orkiestry teatru polskiego ${ }^{3}$. Jak się musiał przewoźnik Styksa zadziwić, słysząc tego przychodnia, gdy już słyszał Meropę [mowa o królowej Messenii z tragedii Woltera pod tymże tytułem J.Ch.]. Jakaż różnica charakterów tych dwóch wielkich z znaczenia osób i jakie położenie ludów przez nie rządzonych. Szczęśliwy naród, gdzie panują Meropy, biedny kraj, któremu ślepe losów zrządzenie przeznaczyło Wampumów. Aktor grający tę rolę raczy odebrać powinszowanie tak znacznego postępu w jego trudnym talencie, raczej to jest tylko mały dodatek do tych poklasków, którymi publiczność grę jego zaszczyca ${ }^{4}$.

Poświadczone obecnością tytułowej postaci w komedyjce Dmuszewskiego powodzenie Suttana Wampuma - drugiej zachowanej i czwartej w ogóle polskiej opery Elsnera - okazało się trwałe, sztukę wystawiano bowiem wielokrotnie w wielu polskich miastach aż po rok I8I $5^{5}$. Uznanie szerszych kręgów publiczności nie zawsze podzielali krytycy. Ostatnie wznowienie sztuki doczekało się recenzji, pochodzącej spod pióra autora należącego do klasycyzującego stronnictwa Iksów, zamieszczonej zaś w Gazecie Korespondenta Warszawskiego i Zagranicznego, gdzie przeczytać można było, że wartość tej „najdowcipniejszej sztuki Kotzebuego” nadwątlona została przez tłumacza, który nie dość, że miejscami zagubił „dowcipną satyrę oryginału”, to jeszcze „zły smak i gminną przesadę okazał”, dodając niektóre nowe fragmenty - choć inne poprzydawał „dość szczęśliwie”6.

2 Ludwik Adam Dmuszewski, Aktorowie na Elizejskich Polach: dzieto teatralne oryginalnie wierszem napisane, Warszawa I802, s. 37-38.

3 Dokładna data premiery Suttana Wampuma nie jest znana, wiadomo tylko, że miała miejsce w roku I8oo, zob.: A. Nowak-Romanowicz, op. cit., s. Io6.

4 Ibid., s. 37. Chwalony tu Alojzy Żółkowski, podówczas młody artysta - stażem na deskach warszawskiego teatru tylko dwa lata od Dmuszewskiego starszy - już niedługo stać się miał pierwszym komikiem Warszawy i jednym z najwybitniejszych polskich aktorów, zob.: Stefan Durski, Ludwik Adam Dmuszewski, Warszawa I974, s. 74-77.

5 A. Nowak-Romanowicz, op. cit., s. IIo. Postać Wampuma wprowadzono także w okolicznościowym „przydatku” do komedioopery Frozyna Adamczewskiego granej II XII I807 r., druk w: Krótki zbiór wierszy, pieśni i mów patriotycznych, przy rozmaitych uroczystościach narodowych, jako też i przy pochowaniu ciat rycerzów polegtych w obronie ojczyzny, [red. Maciej Chmielewski], Warszawa I8o8, s. 86-9I.

6 Recenzje teatralne towarzystwa Iksów, red. Jacek Lipiński, Wrocław 1956 (= Materiały do dziejów teatru w Polsce 4), s. 29-30. Alina Nowak-Romanowicz, przywołując uwagi recenzenta w poświęconej Elsnerowi monografii, pomija to ostatnie zastrzeżenie, przez co odnieść można wrażenie, że polska adaptacja utworu Kotzebuego oceniona została w recenzji zdecydowanie negatywnie, co mija się z prawdą, zob.: A. Nowak-Romanowicz, op. cit., s. I27. 
Tłumaczy było dwóch: sam Wojciech Bogusławski - wielki miłośnik Kotzebuego i autor niejednego przekładu z niemieckiego dramatopisarza - i Augustyn Gliński, tłumacz i zarazem rządowy cenzor sztuk teatralnych, z którym miał Bogusławski jeszcze po wielekroć przy kolejnych dramatach Kotzebuego współpracować. Zarzuty w stosunku do autorów przekładu zdają się jednak omijać istotę sprawy, uważniejszy rzut oka na pozostałe po warszawskiej adaptacji źródła przekonuje bowiem, że przekształcenia oryginalnego libretta pozostawały w ścisłym związk z muzycznym kształtem spektaklu - krótko mówiąc, iż pierwszeństwo należałoby przyznać raczej koncepcji dramatyczno-muzycznej wypracowanej, jak wolno się domyślać, przez Bogusławskiego wespół z Elsnerem (nie wykluczając udziału Glińskiego), która to z kolei warunkowała dopiero literacki kształt polskiej wersji libretta - szczególnie owe „przydatki”, które tak uraziły smak recenzenta ${ }^{7}$. Koncepcji tej, która dotknęła tożsamości gatunkowej dzieła, skutkom jej przyjęcia, niektórym znaczącym rozwiązaniom szczegółowym, wreszcie zaś próbie porównania dramaturgicznej wizji warszawskich adaptatorów z oryginałem Kotzebuego poświęcone są kolejne partie niniejszego artykułu. Zacząć jednak wypada od przybliżenia niemieckiego oryginału sztuki i jego autora.

\section{AUGUST VON KOTZEBUE I JEGO SUETAN WAMPUM}

Dramatopisarstwo Kotzebuego, zaliczane zasadniczo do nurtu sentymentalnego dramatu mieszczańskiego, praktycznie zdominowało życie teatralne obszaru niemieckojęzycznego jak i wielu innych części Europy u schyłku XVIII i w pierwszych dekadach XIX stulecia ${ }^{8}$. Jego wartość okazała się mało odporna na upływ czasu -

7 Trudno powiedzieć, na czym polegała współpraca Glińskiego i Bogusławskiego przy tłumaczeniu libretta. Elsner w Sumariuszu podaje jako tłumacza tylko Glińskiego, a Bogusławski w żadnym ze swoich pism nie przyznaje się do Wampuma jako swojego dzieła, jednak oba nazwiska pojawiają się w Krótkiej kronice Teatru Polskiego Dmuszewskiego. Nowak-Romanowicz, uznając zapewne Sumariusz za najwiarygodniejsze źródło, pisze, że jedyne, co wiemy o udziale Bogusławskiego w tej sprawie, to fakt, że tekst dodatkowej arii Nuradina zaczerpnięty został częściowo z Amazonek, zob.: A. Nowak-Romanowicz, op. cit., s. I06, przyp. I08, powtórzone w: tejże, Klasycyzm 1750-I830, Warszawa 1995 (= Historia Muzyki Polskiej 4), s. I9I, przyp. 137. Aria ta jednak została dołączona do materiałów do Suttana Wampuma omyłkowo i w rzeczywistości do niej nie należy, zob.: Jakub Chachulski, „Fragment zaginionego singspielu Józefa Elsnera”, Muzyka 64 (2019) nr 3, s. 99-109. Raszewski pisze o Wampumie jako o dziele Bogusławskiego (op. cit., t. II, s. 79). Biorąc pod uwagę I) dominującą pozycję Bogusławskiego, płynącą zarówno z zajmowanego stanowiska reżysera i dyrektora teatru, jak i ogromnego, wielostronnego doświadczenia scenicznego, 2) fakt, iż tłumaczenie poprzedzone musiało być wstępną decyzją o przyjęciu nowej muzyczno-dramatycznej koncepcji sztuki, 3) niemal dosłowne tłumaczenie dialogów mówionych, postawić można byłoby hipotezę, że wkład Bogusławskiego najpewniej ograniczony był do wspomnianej ogólnej koncepcji (udział w niej mógł mieć także i Elsner), być może także przekładu (niektórych?) numerów śpiewanych, podczas gdy Gliński wziął na siebie faktyczną pracę tłumacza, na którą Bogusławski mógł po prostu nie mieć czasu.

8 Szacuje się, że w l. I795-I825 dzieła Kotzebuego stanowiły około ćwierci repertuaru niemieckich teatrów, zob.: Benno von Wiese, [Wstęp] w: August von Kotzebue, Schauspiele, red. Jürgen Mathes, Frankfurt am Main 1972 , s. 7. 
ktoś złośliwy powiedzieć mógłby, że najtrwalszym osiągnięciem literackim okazała się śmierć Kotzebuego, który, podejrzewany o szpiegostwo na rzecz Rosji, zginął w I8I9 r. zasztyletowany przez młodego niemieckiego „patriotę”, członka korporacji studenckiej: wydarzenie to odbiło się w Europie szerokim echem, a jego legenda trafiła jeszcze na karty Czarodziejskiej góry Tomasza Manna.

Miernie utalentowany jako pisarz - pisze Zbigniew Raszewski - Kotzebue odznaczał się jakimś szczególnym zmysłem, który pozwalał mu nieomylnie trafiać w zapalne punkty ówczesnych zainteresowań i dostosowywać się do nastrojów epoki. Główną nutą swojej ideologii uczynił dosyć ogólnikowy humanitaryzm, domagając się od wszystkich wspaniałomyślności i litości, także dla wzgardzonych i poniżonych, dla ludzi innego stanu, wyznania, języka i rasy, nawet dla najgorszych wrogów. Hasła te były już wtedy publiczności teatralnej dobrze znane. Wszelako szokująco działała śmiałość, z jaką je Kotzebue odnosił do konkretnych przykładów, szczególnie na gruncie obyczajowym?.

Staraniem Bogusławskiego sztuki niemieckiego dramatopisarza zaczęły pojawiać się na deskach polskich teatrów, gdy tylko o Kotzebuem zrobiło się głośniej w Prusach i Rosji; sztuka Nienawiš́c ludzi i żal miała swą warszawską premierę tuż po berlińskiej, w I79I r., a w następnej dekadzie wystawił Bogusławski blisko dziesięć kolejnych sztuk niemieckiego autora (także z niemieckim zespołem teatralnym we Lwowie) ${ }^{\text {ro }}$. W Aktorach na Elizejskich Polach Dmuszewskiego nad Styksem pojawiają się postaci z trzech sztuk Kotzebuego - żaden inny dramatopisarz nie jest tu reprezentowany tak licznie.

Libretta operowe stanowią zasadniczo margines twórczości Kotzebuego, choć odnaleźć można wśród nich jeden z ciekawszych i popularniejszych utworów niemieckiego dramatopisarza - Pustelnik na wyspie Formentera ${ }^{\text {II }}$. We wstępie do pierwszego libretta Kotzebuego, Spiegelrittera, znaleźć można bez ogródek wypowiedzianą opinię pisarza o operze, autor wyraża tam bowiem nadzieję, że czytelnik uzna tę sztukę za „równie błazeńską, awanturniczą i niedorzeczną („närrisch, abentheuerlich und albern”) jak ,jej starsze siostry z niemieckich scen”"2. Krótki przegląd librett Kotzebuego potwierdza sens tej wypowiedzi, jako że autor podejmuje w nich niemal wyłącznie takie tematy, które ze względu na elementy fantastyki czy cudowności - bądź właśnie „niedorzeczność” - nie mogłyby znaleźć się w realistycznej sentymentalnej dramie mieszczańskiej ${ }^{13}$. Wszystkie też opierają się przede wszystkim na dialogach

9 Zbigniew Raszewski, Bogustawski, Warszawa 1972, t. I, s. 300-30I.

IO Ibid., s. 30I-306 i dalej.

II O twórczości operowej Kotzebuego zob.: Karin Pendle, „August von Kotzebue, Librettist”, The Journal of Musicology 3 (1984) nr 2, s. 196-213; Thomas Bauman, North German opera in the age of Goethe, Cambridge 1985, s. 247-248, 274-279.

I2 August von Kotzebue, Theater von August v. Kotzebue, t. 3, Leipzig I840, s. 3.

I3 K. Pendle, op. cit., s. 20I. Por. także: Anna Papierzowa, Libretta oper polskich z lat 1800-1830, Kraków 1959, s. I2I. W Polsce, jak się wydaje, konwencji tego rodzaju nie przestrzegano aż tak ściśle: Wojciech 
mówionych, obracając się, pomimo różnych używanych określeń gatunkowych, w granicach szeroko rozumianego singspielu ${ }^{\mathrm{I} 4}$.

Napisany w 1790 r. Suttan Wampum był drugim z kolei librettem Kotzebuego ${ }^{\text {I5 }}$. Zawiera stosunkowo niewiele typowej dla autora przejaskrawionej emocjonalności; intryga opiera się na komediowym ujęciu modnych podówczas wątków orientalnych i czarodziejskich ${ }^{16}$. Na scenie pojawia się wschodni despota sułtan (czy też szach) Wampum, przywódca jego „czarnoskórych rzezańców” Hussein, nieodzowny dla perskich baśni geniusz i stereotypowa para sentymentalnych kochanków - młody, bogaty kupiec Nuradin i uboga sierota - piękna Alma. Liczby postaci dopełniają prostacki sługa Nuradina Kaled, europejski lekarz na usługach sułtana i dwóch szyldwachów, a także sułtańscy muzycy, czyli chór. Akcja trzyaktowego dramatu Kotzebuego przedstawia się następująco ${ }^{17}$ :

AKT I

Alma śpiewa przy źródle. Zatrzymuje się przy nim także powracająca do Szirazu karawana Nuradina. Kaled, natknąwszy się na Almę, chce zmusić ją do zdjęcia zasłony z twarzy, nadchodzi jednak Nuradin i karci go surowo; sam wszakże zaciekawiony przekonuje Almę do pokazania twarzy, tłumacząc, iż chciałby być tylko jej bratem, któremu przecież twarz wolno pokazać. Alma zdejmuje zasłonę, zachwycony Nuradin natychmiast wyznaje jej miłość i chce ją poślubić jeszcze tego samego dnia. Alma odpowiada, że chociaż go nie kocha, to z czasem jej uczucia może się odmienią. Nuradin zabiera ja ze sobą; wygnany ze służby Kaled odchodzi i poprzysięga zemstę.

Tymczasem w pałacu widzimy ziewającego sułtana. Upewniwszy się, że przyczyną ziewania nie jest senność, władca zaczyna obawiać się o swoje zdrowie i wzywa europejskiego lekarza. Ten wyjaśnia mu, że sułtańską dolegliwością jest nuda; zaleca więcej zajęć i zachęca do większej troski o sprawy poddanych i państwa. Wyjaśnienie to nie przekonuje

Bogusławski w toku przekładu na język polski przekształcił Pustelnika z wyspy Formentera w dramat posługujący się wyłącznie słowem mówionym, por.: Wojciech Bogusławski, Dzieła dramatyczne, t. Io, Warszawa I832. Nie zabrakło natomiast początkowej symfonii przedstawiającej burzę na morzu (być może nawet wziętej z oryginalnej muzyki Ernsta Wilhelma Wolffa?), por.: Z. Raszewski, op. cit., t. 2, s. I44.

I4 K. Pendle, op. cit., s. 198.

I5 T. Bauman, op. cit., s. 276.

I6 Utwór można zaliczyć do tzw. Türkenopern o librettach opartych na typowym motywie fabularnym „uprowadzenia” - jak Uprowadzenie z seraju Mozarta czy Axur Salieriego, zob.: Agata Pawlina, „Przegląd wątków orientalnych w muzyce klasycznej Europy w kontekście saidowskiej teorii orientalizmu”, Przegląd Orientalistyczny 67 (2016) nr I-2, s. I96. Orientalny sztafaż opery Kotzebuego nie wykracza jednak poza konwencję i trudno oczekiwać interesujących wniosków w wyniku doszukiwania się w dziele europejskiego obrazu orientu, wręcz przeciwnie - miejscami wydaje się, że postać sułtana jest swoistą maską umożliwiającą bezpieczną krytykę europejskiego despotyzmu. Satyryczny aż do utraty ostatniego śladu monarszego dostojeństwa obraz sułtana w Wampumie pozostaje raczej nietypowy dla orientalnych fascynacji epoki - by przywołać chociażby postać groźnego, lecz łaskawego władcy z Uprowadzenia z seraju, naśladowaną w niemieckim singspielu Elsnera i Brettschneidera Der verkleidete Sultan (1795).

I7 Streszczenie libretta podane przez Annę Papierzową (op. cit., s. 227) zawiera pewną liczbę nieścisłości, tu opieram się na niemieckim oryginale: A. von Kotzebue, Theater, op. cit., t. 4, Leipzig I840, s. I-72. 
Wampuma. Hussein doradza mu rozmaite rozrywki, w tym ścinanie głów niewolnikom, wreszcie zrozumiawszy, że sułtanowi potrzeba świeżych wrażeń, radzi sprowadzić do pałacu nowe, piękne dziewczęta. Wampum jest zachwycony i nagradza Husseina spełnieniem jego życzenia, to jest ścięciem głowy Wezyra. Nowym wezyrem ma zostać ten, kto sprowadzi sułtanowi najpiękniejsze dziewczę. Wampum domaga się spokojnego śpiewu od pałacowych muzyków i ukołysany nim zasypia.

AKT II

Gdy Wampum, zbudziwszy się, dowiaduje się od Husseina, iż poszukiwania pięknych dziewcząt nie odniosły skutku, do pałacu przybywa Kaled i opowiada władcy o Almie. Wampum każe sprowadzić ją do siebie. W tym celu oddaje pod komendę Kaleda oddział janczarów i wręcza mu swój rozkaz na piśmie.

Tymczasem Nuradin rozmawia w swoim domu z Almą. Dziewczyna zaczyna odczuwać miłość do młodego kupca. Nadchodzi Kaled i pokazuje sułtański rozkaz. Nuradin rzuca się na niego ze sztyletem, w tym momencie Kaled wzywa janczarów, którzy obezwładniają kupca i zabierają dziewczynę do pałacu.

Sułtan, ujrzawszy Almę, jest zachwycony. Zapowiada, że jeśli mu nie ulegnie, uśmierci Nuradina. Daje jej dwie godziny do namysłu. Akt zamyka groteskowa śpiewka Kaleda o tym, jak też wesoło będzie spędzał czas teraz, gdy, zgodnie z sułtańską obietnicą, został mianowany wezyrem.

AKT III

Zrozpaczony Nuradin, rozmyślając o swym nieszczęściu, wypowiada życzenie - chciałby choć na godzinę przybrać postać sułtana, aby móc wejść do pałacu. Pojawia się Geniusz, który daje Nuradinowi pierścień; przy jego pomocy kupiec przybiera postać sułtana i udaje się do pałacu.

W tym czasie sułtan podczas przechadzki zastanawia się, jak zmusić Almę do uległości. Wypowiada życzenie - chciałby przybrać postać Nuradina i w ten sposób zwieść dziewczynę. Ukazuje mu się Geniusz i obdarza go takim samym pierścieniem jak wcześniej Nuradina. Sułtan w postaci kupca próbuje wejść do pałacu, lecz Kaled, biorąc go za Nuradina, zatrzymuje go i każe strażnikom zamknąć w lochu.

Także Alma, z przerażeniem oczekująca Wampuma, wypowiada życzenie - chce mieć truciznę, by wrzucić ją do sorbetu, który ma podać Wampumowi na znak swej uległości. Pojawia się Geniusz i spełnia jej prośbę. Nadchodzi Nuradin w postaci sułtana, Alma podaje mu kielich, sama także pije. Nuradin mówi, kim jest i na moment wraca do swojej postaci. Kochankowie obejmują się, pragnąc umrzeć razem. Nadchodzą szyldwachowie, prowadząc pojmanego sułtana w postaci Nuradina.

W tym momencie rozlega się grzmot i pojawia się Geniusz. Zwraca obu mężczyznom ich własną postać, uzdrawia Almę i Nuradina, po czym życzy im szczęścia. Na protesty i groźby Wampuma odpowiada, że bierze młodych pod swoją opiekę, po czym wypowiada końcową naukę: próżno śmiertelnym rozmyślać, dociekać, życzyć sobie i pragnąć: stworzeni są do tego, co małe i ograniczone, ich przewidywania wiodą na manowce, to zaś, czego im potrzeba, dostają i tak z rąk przeznaczenia. Następnie Geniusz znika. Sułtan nic z tego nie rozumie; wzywa pałacowych śpiewaków, przy których śpiewie zasypia jak na końcu aktu I. 
Komiczną dominantą sztuki jest groteskowo przerysowana postać tytułowego satrapy - okrutnika i żarłoka, przede wszystkim jednak absolutnego głupca - w istocie już na granicy patologii - któremu na domiar złego sprawowana władza absolutna pozwala z pogardą ignorować wszystko, czego nie rozumie ${ }^{\mathrm{I}}$. Obok elementów miejscami niemal rabelaisowskiego humoru i sentymentalnej intrygi miłosnej dziełko Kotzebuego zawiera w sobie także elementy pozwalające widzieć w nim coś więcej niż tylko rozrywkę dla gawiedzi, takie jak postępowa krytyka despotyzmu, dążenie do pewnego rodzaju psychologicznego pogłębienia wątku Almy i Nuradina, czy wreszcie niebanalne przesłanie sztuki, wprost wyartykułowane w końcowym, pouczeniu Geniusza.

Także i sam humor Kotzebuego, przy całej swej drastyczności (stały motyw rozmaitych a dotkliwych kar cielesnych wymyślanych przez sułtana dla swych poddanych czy niedwuznaczne, cyniczne żarty Kaleda i Husseina kierowane pod adresem sprowadzonej do pałacu Almy) nie wydaje się „gminny”, lecz skierowany, przynajmniej miejscami, do publiczności dysponującej pewnym szlifem umysłowym. Wampum pyta opowiadającego o swej przeprawie przez pustynię Kaleda, czemu nie wybrali dogodniejszej drogi i czemu nie pili wina, gdy zabrakło im wody (zapewne czytelna aluzja do znanego zdania o ciastkach przypisywanego Marii Antoninie Austriaczce), nieco dalej rozkazuje wygnać z państwa jaskółki i gąsienice, gdzie indziej zaś, poproszony przez Husseina o wyjaśnienie swojej ewidentnie sprzecznej wypowiedzi odpowiada: „Was aufklären! Ich liebe die Aufklärung nicht” (gra słów zasadza się na dwuznaczności słowa „Aufklärung”: nie wiadomo, czy władca nie lubi wyjaśniania, czy oświecenia ${ }^{19}$. Jesteśmy tu dość daleko od ludycznego, miejscami rubasznego komizmu, jaki znaleźć można w Amazonkach Bogusławskiego i Elsnera, bliżej zaś satyry cenionej zapewne w kręgach warszawskiego recenzenta cytowanego na początku niniejszego artykułu.

Dziełko Kotzebuego, określone przez autora jako „Ein orientalisches Scherzspiel mit gesang” („orientalna sztuka komiczna ze śpiewem”), zbudowane zasadniczo z mówionej prozy ubarwionej okazjonalnymi numerami śpiewanymi, można zaliczyć do szeroko rozumianego gatunku singspielu ${ }^{20}$. Można by zastanawiać się

I8 Na kilka lat przed premierą utworu Elsnera operę do oryginalnego tekstu Kotzebuego napisał i chciał wystawić w Warszawie Maciej Kamieński, cenzura jednak nie dopuściła do premiery, podejrzewając, że postać władcy ma być aluzją do panującego Fryderyka Wilhelma II. W I8oo r. Prusami władał już Fryderyk Wilhelm III, nie budzący podobnych skojarzeń, zob.: A. Papierzowa, op. cit., s. 5I.

I9 A. Kotzebue, Theater, op. cit., s. 30, 38, 48.

20 Mówiąc o singspielu w kontekście polskiej twórczości operowej początku XIX w., obficie czerpiącej z ówczesnego francuskiego wodewilu, dokonać trzeba koniecznych rozróżnień. Oba gatunki wraz z pokrewną angielską ballad opera łączy użycie numerów muzycznych jako incydentalnych „wstawek” pojawiających się pomiędzy mówionymi dialogami, singspielu jednakże nie da się ostro odgraniczyć od opery komicznej z mówionymi dialogami, por.: Peter Branscombe, „Opera IV, 2”, w: New Grove dictionary of music and musicians, t. I3, London I980, s. 585-589, zob. zwłaszcza s. 585, 586. Wojciech Bogusławski opisuje singspiel jako „niemiecką operą komiczną”, zob.: tegoż, Dzieła dramatyczne, t. I, 
nad odniesieniem do Wampuma słów Kotzebuego ze wstępu do innego, niewiele późniejszego utworu, w którym pisał on, że rad byłby powrócić do starej operetki (Operette) niemieckiej, która „wiele wspólnego miała z francuskim wodewilem” - sztuki „interesującej także bez muzyki”, a jedynie ubarwionej rozrzuconymi tu i ówdzie „małymi piosenkami” („kleine Liederchen”) ${ }^{21}$. Nie należy jednak zbyt lekko przyjmować tego ostatniego stwierdzenia - utożsamienie „wstawkowego" charakteru numerów muzycznych singspielu $\mathrm{z}$ ich czysto ornamentalną, niesubstancjalną funkcją traktowane było przez część krytyków i teoretyków gatunku za nieporozumienie, przeoczające fakt, że to właśnie sporadyczne pojawianie się na scenie muzyki pozwalało wykorzystać ją w roli kluczowego emocjonalnie elementu poszczególnych scen ${ }^{22}$.

Libretto Kotzebuego przejawia bardzo swoiste i w pełni konsekwentne podejście do kształtowania miejsca i funkcji numerów śpiewanych w całości utworu podejście, które najlepiej uwydatnić można, definiując ich stosunek do położonych na przeciwległych biegunach operowej arii i wodewilowej piosenki. Zasadniczą odmienność tych dwóch rodzajów scenicznych numerów wokalnych, rozważanych jako współczynniki libretta - a więc abstrahując od ich konkretnego kształtu muzycznego - ująć można w dwóch punktach. Pierwsza różnica dotyczy miejsca muzyki w semantycznej strukturze dzieła sztuki, jakim jest spektakl teatralny. W typowym wodewilu - np. w komediooperach Dmuszewskiego - śpiewane przez postaci piosenki czy ,śpiewki” są nimi także z punktu widzenia akcji dramatu, lub też, by ująć rzecz z właściwą precyzją, śpiew nie jest w nich sposobem przedstawiania, lecz tym, co przedstawiane. Tymczasem w operowej arii muzyka, a więc i śpiew, pozostają środkami przedstawiającymi: postaci dramatu, mówiąc nieco humorystycznie, nie wiedzą, że śpiewają - niczym nie przymierzając molierowski pan Jourdain, nieświadom tego, że mówi prozą. Drugą istotną cechą odróżniającą wodewilową piosenkę od arii jest pewne oderwanie tej pierwszej od konkretnej akcji dramatu, przejawiające się w poruszaniu podejmowanych w sztuce problemów obyczajowych, społecznych czy moralnych i w postaci prawdy ogólnej, morału albo satyry na rzeczywistość społeczną; piosenka taka jako wehikuł dydaktycznej czy propagandowej treści utworu nadaje wodewilowi ów szczególny, na poły otwarty charakter przedstawienia wychodzącego niejako w stronę aktualnej rze-

\footnotetext{
Warszawa I820, s. 36I-362. Wczesna opera polska za sprawą wpływów wiedeńskich wiele zawdzięcza południowoniemieckiemu singspielowi, niezależnie od tego $\mathrm{w}$ początkach XIX w. pojawia się na ziemiach polskich wodewil jako bezpośrednio importowana z Paryża „komedioopera” - a zarazem następca „komedii z piosenkami” czasów stanisławowskich - wyraźnie odgraniczona od ukształtowanej już postaci opery komicznej, zob.: S. Durski, Dramatopisarstwo, op. cit., s. 47-48.

2I [August von Kotzebue], Neue Schauspiele von August Kotzebue, Leipzig 1798, s. 433.

22 Zob.: T. Bauman, op. cit., s. 219-222. Szczególnie znamienna jest przytoczona tam anonimowa recenzja zamieszczona w I783 r. w Literatur und Theatre-Zeitung, której autor broni odrębności singspielu zarówno od opery, jak i komedii.
} 
czywistości ${ }^{23}$. W odróżnieniu od takiej piosenki operowa aria pozostaje w ścisłym i nierozerwalnym związku z akcją, będąc aktem bezpośredniej ekspresji uczuć tej czy innej postaci dramatu ${ }^{24}$.

Otóż, co ciekawe, wszystkie numery muzyczne Wampuma konsekwentnie ukształtowane są jako ściśle określona forma pośrednia między tak rozumianą arią i piosenką wodewilową. Nie przejawiają one cech wodewilowych w drugim wymienionym sensie, ponieważ element typowo wodewilowego morału, satyry czy prawdy ogólnej w ogóle w nich nie występuje, zarazem jednak pod względem pierwszego z wymienionych kryteriów jednoznacznie dystansują się od numerów typu operowego. Pomimo bowiem ewidentnie ekspresyjnej funkcji niektórych z nich, jak początkowego śpiewu Almy czy następującego po nim jej duetu z Nuradinem, Kotzebue z pełną konsekwencją przedstawia wszystkie numery muzyczne jako „utwory w utworze”, rzeczywisty śpiew z punktu widzenia akcji dramatu, a nawet czyni sam śpiew istotnym - choćby i niepierwszoplanowym - tematem utworu ${ }^{25}$. I tak, opowiadając Wampumowi o spotkaniu Almy, Kaled wspomina o jej śpiewie przy źródle, nie umie go jednak powtórzyć, w odpowiedzi zaś na zarzut sułtana, że pewnie w ogóle śpiewać nie potrafi, przedstawia swą opowieść w formie śpiewanej romanzy. Gdy Alma zostaje sprowadzona na dwór, władca każe jej śpiewać, a zachwycony jej piosenką wydaje rozkaz, by wszyscy na dworze posługiwali się już odtąd śpiewem zamiast mową, czym daje z kolei pretekst dla komicznych duetów dwu szyldwachów, skarżących się śpiewem na sułtańskie rozporządzenie i swoje wokalne niedostatki. Owa „tematyzacja” śpiewu przydaje szczególnego znaczenia okoliczności, że jedyną postacią wyłącznie śpiewającą jest

23 W tym sensie wodewilowa jest np. również aria Strabona „Prawda jest gorzką potrawą” z Amazonek i stąd zapewne jej wykraczająca poza deski teatru popularność, o której pisze Zbigniew Raszewski (op. cit., t. 2, s. 304, przyp. 68). Owa luźna przynależność piosenek do akcji dramatu pozwala zarówno na włączanie istniejących piosenek do nowych wodewilów, jak i działania odwrotne - Dmuszewski np. dopisał nowy, aktualny politycznie tekst do jednego z numerów przy wznowieniu komedioopery Siedem razy jeden tuż po ustanowieniu Księstwa Warszawskiego, zob.: S. Durski, Dramatopisarstwo, op. cit., s. 67-68.

24 O ile druga z wymienionych cech pozostaje niezbywalnym elementem każdej definicji wodewilu i form pokrewnych (zob. np.: S. Durski, Dramatopisarstwo, op. cit. s. 42-50), pierwsza, choć uznana być może za jeden z kluczowych - bo dotykających głębokiej struktury dzieła scenicznego - aspektów różnicy pomiędzy operą a wodewilem, w historycznie nastawionej muzykologii przechodzi najczęściej niezauważona, co można zresztą uznać za w dużej mierze uzasadnione, jeśli zważyć, że twórcy muzycznych gatunków scenicznych rzadko dbali w tej kwestii o konsekwencję. (W odniesieniu do opery z estetycznego punktu widzenia rzecz omawia Peter Kivy, zob. tegoż, „Speech, song, and the transparency of medium: On operatic metaphysics", w: Music, language, and cognition: and other essays in the aesthetics of music, Oxford 2007, s. 5I-6I.)

25 Sam zabieg nie jest oczywiście odosobniony w ówczesnej twórczości - podobnie jest chociażby w Echu $w$ lesie Elsnera, gdzie występują numery o charakterze raczej operowym funkcjonujące zarazem na wodewilowej zasadzie „utworu w utworze”, jednakże pełna konsekwencja Kotzebuego w stosowaniu w Wampumie wyłącznie tego typu numerów na przestrzeni dość długiej, trzyaktowej sztuki, zasługuje na uwagę. 
Geniusz, jedyną zaś z głównych postaci, która nie śpiewa - tytułowy satrapa ${ }^{26}$. Nie waha się tu zresztą Kotzebue przed aluzją do etycznie podejrzanego charakteru muzyki przy samym już końcu sztuki. Gdy Nuradin radzi sułtanowi czerpać odtąd przyjemność z czynienia dobra („Die Freude wohl zu thun”), Wampum, nie rozumiejąc, w czym rzecz, odpowiada: „Przyjemność? Niech przyjdą moi śpiewacy, chcę mieć przyjemność z muzyki” („Genießen? Laßt meine Sänger hereintreten; ich will Musik genießen").Tą eksponowaną rolą muzyki należy prawdopodobnie tłumaczyć fakt, że, wybrawszy gatunek i konwencję wskazujące raczej na użycie niewyszukanych form muzycznych, Kotzebue w numerach śpiewanych unika jednak prostych form stroficznych, sugerując ambitniejsze gatunki wokalne.

Druga w libretcie Kotzebuego rzecz ciekawa i oryginalna to identyczne zakończenia pierwszego i trzeciego aktu (a więc i całości opery) - sceną, w której monarcha wzywa swoich muzyków i zasypia do wtóru ich chóralnego śpiewu (poniżej obok oryginalnego tekstu podaję tłumaczenie Bogusławskiego-Glińskiego):

Er schlummert - stille - stille!

Höret den Monarchen

Melodievoll schnarchen! -

Welch' ein feistes Stöhnen! -

Welch' ein fetter Klang! -

Es ersterbe der Gesang

In immer schwächern Tönen,

Stille! Stille

\author{
Słuchajcie jak sapie, \\ jak przyjemnie chrapie, \\ jak z gardziołki pulchniutkiej, \\ wychodzi ton słodziuchny, \\ niech się ścisza śpiewanie, \\ a na koniec zostanie \\ cicho, cicho...
}

W rezygnacji z hucznego, jednoznacznego finału eksponującego w pierwszym rzędzie szczęśliwe rozwiązanie wątku miłosnego znać pewną autorską powścią-

26 W rozwiązaniu tym można dopatrywać się aluzji do nieśpiewającej postaci baszy Selima z Uprowadzenia z seraju, choć jak twierdzi Mary Hunter, ograniczanie śpiewu postaci wschodniego despoty było szerszą tendencją europejskich Türkenoper, zob.: tejże, „Alla Turca style in the late eighteenth century: Race and gender in symphony and seraglio”, w: The exotic in Western music, red. Jonathan Bellman, Boston I998, s. 43-73, zob. zwłaszcza s. 63. Nie była to jednak chyba tendencja powszechna, skoro np. nieco pokrewny Wampumowi swym groteskowo-sadystycznym charakterem Axur z cieszącej się olbrzymim powodzeniem orientalnej abduction-opera Salieriego otrzymał regularną rolę basową o komicznym miejscami charakterze. Jakakolwiek by była geneza tego pomysłu, fakt niemuzykalności sułtana otrzymał u Kotzebuego własną, oryginalną wymowę ściśle związaną z „muzyczną” tematyką dzieła. Diametralna różnica w kreacji roli wschodniego władcy w Uprowadzeniu i Wampumie przy innych, drobnych, lecz znaczących podobieństwach mających zarazem charakter nawiązania à rebours (służący głównego bohatera przechodzący na służbę władcy - u Mozarta z musu i pozornie, u Kotzebuego z zemsty - mający w swej partii romanzę i trienklied, zamknięcie całości chórem janczarów identycznym lub blisko spokrewnionym z takimże chórem z I aktu - w Uprowadzeniu pochwalnym, w Wampumie parodystycznym) mogłaby nasuwać myśl o autorskiej intencji stworzenia przewrotnej trawestacji szeroko znanego i podziwianego singspielu Mozarta. 
gliwość, która, bacząc na zasadniczą skłonność Kotzebuego do uczuciowej efektowności i taniej chwytliwości, daje do myślenia. Akcja zatacza koło, podkreślając niezmienność porządków panujących na dworze sułtana: zamknięcie sztuki spojrzeniem na zasypiającego jak w pierwszym akcie despotę zdaje się wskazywać na nieuleczalność sułtańskich wad - a może i samego despotyzmu władzy jako nieuleczalnego defektu świata. Zarazem ta na wpół poetycka, na wpół humorystyczna cyrkularność zakończenia, dystansując się od perypetii romansowej fabuły, pozostawia miejsce dla refleksji: czy wymowa dramatu wyartykułowana w końcowej nauce Geniusza, by „nie dociekać, nie żądać, nie pragnąć”, to na pewno pogodne wezwanie do zaufania wyrokom losu lub Opatrzności - jak chciałyby zapewne wolnomularskie sympatie Elsnera i Bogusławskiego - czy raczej fatalizm, podszyty gorzkim sceptycyzmem rozczarowanego sobą Oświecenia?

\section{SUETAN WAMPUM ELSNERA, BOGUSŁAWSKIEGO I GLIŃSKIEGO}

O warszawskiej adaptacji sztuki Kotzebuego wiemy dziś tyle, ile mówią nam zachowane źródła. Obok starannego autografu partytury, dającego nam pełny wgląd w całość muzycznej tkanki dzieła, Biblioteka Narodowa w Warszawie przechowuje także rękopis partii Husseina, zawierający również rolę mówioną - i to jest niestety wszystko, co posiadamy z niemuzycznej części polskiego libretta ${ }^{27}$. Zestawienie wymienionych przekazów z oryginalnym tekstem Kotzebuego daje jednak solidną podstawę do orzekania o pełnym kształcie warszawskiej wersji Wampuma. Przemawiają za tym następujące przesłanki:

I. Partytura zawiera muzyczne opracowania wszystkich numerów zawartych $\mathrm{w}$ oryginalnym libretcie, $\mathrm{z}$ wyjątkiem mało istotnego ominięcia drugiego $\mathrm{z}$ trzech duetów szyldwachów.

2. Trzy dodane numery solowe daje się precyzyjnie zidentyfikować jako przekształcone fragmenty mówionej części oryginalnego libretta bądź zlokalizować jako w dość naturalny sposób wstawione w tok oryginalnego tekstu.

3. Dwa obszerne, wieloodcinkowe muzyczne finały, dodane przez Elsnera i Bogusławskiego, ściśle odpowiadają akcji oryginalnego libretta (z pewnym wyjątkiem u samego końca opery, o którym później).

4. Zachowana partia mówiona Husseina jest ścisłym, słowo w słowo tłumaczeniem oryginału Kotzebuego z didaskaliami włącznie, w istocie grzeszącym nieraz

27 Wymienione pozycje znajdują się w Bibliotece Narodowej w Warszawie pod sygnaturami MUS.86/I-3 (https://polona.pl/item/sultan-wampum-i-akt,MzcIODI 4 NQ; https:/polona.pl/item/sultan-wampum-ii-akt, MjIIMzUwMzc; https://polona.pl/item/rola-husseina-w-operze-sultan-wampum-i-ii-akt,MjIIMzUwMzk, dostęp 29 IV 2019). Słowa jednej z arii przedrukowano także w pierwszym tomie Śpiewów i aryj teatralnych i światowych z różnych oper i komedyi zebranych z dodatkiem nowych pieśni i krakowiaków, Warszawa I82I, s. II8-I2I. 
dosłownością (próbkę zacytuję w dalszym toku artykułu), z wyjątkiem tych fragmentów, które zostały zastąpione dodanymi numerami muzycznymi.

Wydaje się więc, że możemy z niemal stuprocentową pewnością i dużą precyzją określić, co zrobił Elsner (wespół z Bogusławskim i Glińskim) ze sztuką Kotzebuego: przekształcił mianowicie oryginalną „orientalną komedię ze śpiewami” w orientalną operę komiczną $a^{28} \mathrm{z}$ rozbudowanymi, wieloodcinkowymi finałami wywodzącymi się z tradycji opery buffa, pozostawiając konstrukcję całości utworu oraz proporcje tekstu mówionego do muzyki z grubsza też same co w poprzedniej operze stworzonej razem z Bogusławskim, to jest w Amazonkach. Oryginalną intrygę dramatu pozostawiono bez żadnych zmian (ze wspomnianym wyjątkiem), zaś oryginalne libretto przełożono niemalże dosłownie, zastępując je lub uzupełniając nowymi tekstami tylko tam, gdzie miały pojawić się nowe ustępy muzyczne. Jedyną istotną zmianą strukturalną było zmniejszenie liczby aktów z trzech do dwóch ${ }^{29}$. Porównanie struktury niemieckiego libretta i jego warszawskiej adaptacji, z wyszczególnieniem numerów muzycznych (numerację cyframi rzymskimi podano według partytury Elsnera) i podziału na akty przedstawia poniższe zestawienie:

\author{
Wykaz skrótów \\ K. - August von Kotzebue \\ E. - Józef Elsner
}

28 Termin „opera komiczna” przyjmuję za Aliną Nowak-Romanowicz na określenie utworów zawierających mówione dialogi, lecz pomimo to - w odróżnieniu od wodewilowych komediooper - ciążących w stronę ciągłości muzycznej tkanki (szczególnie przy końcach aktów), a przy tym mających charakter pełnowymiarowej opery. Tak zresztą określa Wampuma sam Elsner (J. Elsner, "Geschichte des polnischen National-Theaters in Warschau”, Allgemeine Musikalische Zeitung I4 (I8I2) nr 50, s. 327). Pierwszym tego rodzaju utworem na gruncie polskim były Amazonki Elsnera. Należy jednak pamiętać, iż forma taka była typowa dla polskich adaptacji oper buffa i semiseria, licznie wystawianych przez Bogusławskiego w czasach stanisławowskich i później - biorąc pod uwagę pozostającą w orbicie Wiednia formację muzyczną Elsnera i jego mozartowskie sympatie (zob.: J. Elsner, Sumariusz, op. cit., s. 98; A. Nowak-Romanowicz, Józef Elsner, op. cit., s. 39) doskonale widoczne w stylu numerów solowych i ansambli oper Elsnera (zob.: A. Nowak-Romanowicz, Józef Elsner, op. cit., s. I08, a także dalsze uwagi zawarte w niniejszym artykule), ujęcie lwowskich i warszawskich oper Elsnera i Bogusławskiego jako twórczej kontynuacji wspomnianej linii „polskiej opery włoskiej” wydaje się dobrze uzasadnione.

29 Niemieckie libretto niejeden raz wprowadziło w błąd piszących o operze Elsnera - o Suttanie Wampumie jako utworze trzyaktowym pisze Anna Papierzowa (patrz wyżej przyp. I4) czy Igor Bełza (Portrety Romantyków, przekł. Ewelina Sułkowska, Warszawa 1974, s. 2I). 


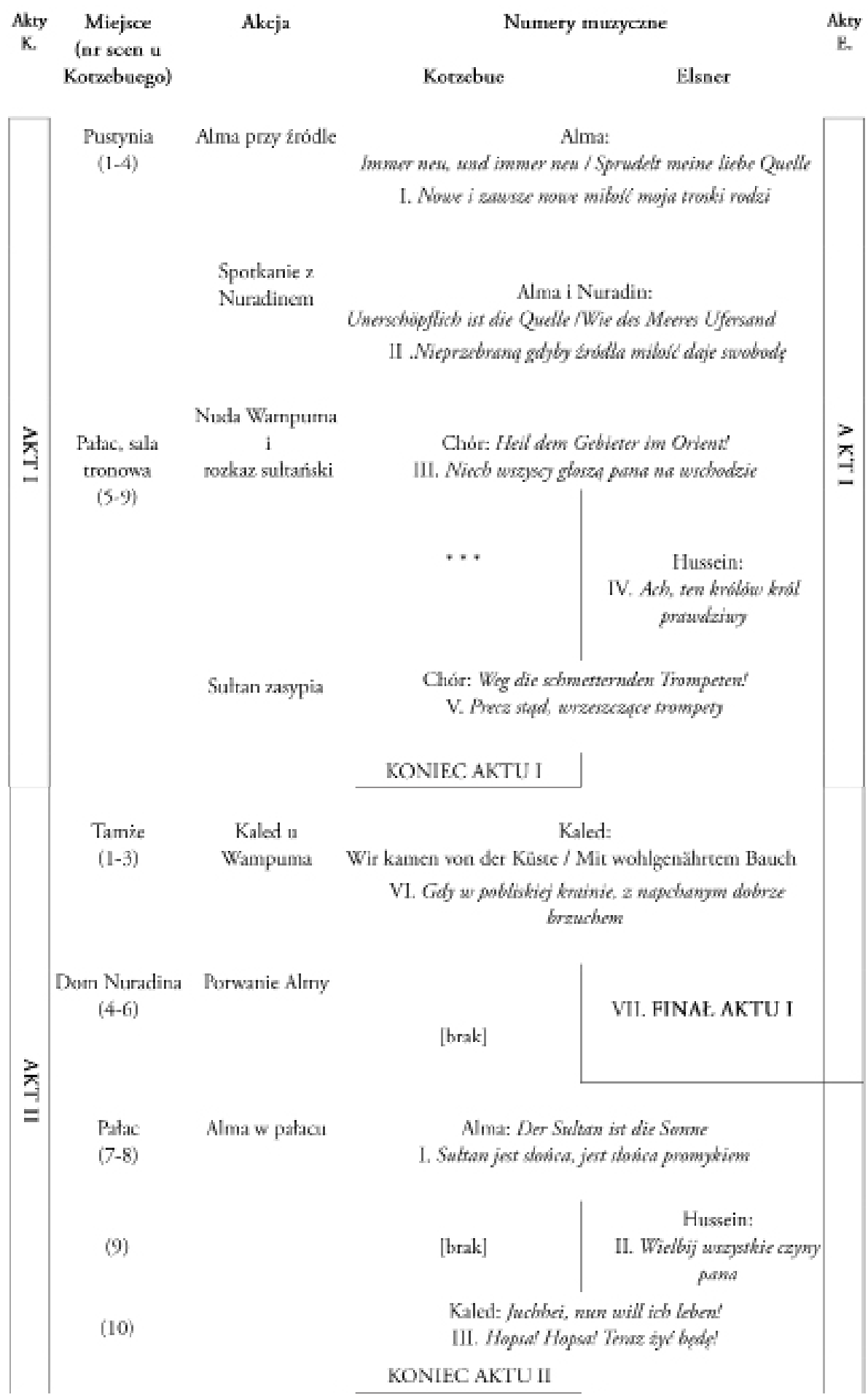


Driedzi-

niec palacowy Wampum rusza na

(1-3) przechadzkৎ

Szyldwachawie:

lch soll singen snd kann nichn!

IV. Jo miaw spiework nic moge?

Tamie Nuradin [brak]

(4-6) i

Geniusz.

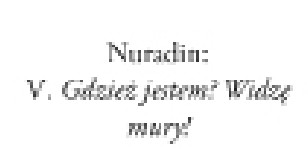

Genius::

Vow funkeludew Abendstern

VL. Przedwicsenych bagiw maof

Tamże

(7)

Nuradin/
Wampum wchodzi
do palacu

Szyldwachowie:

Hor'; Kancrad? war das der
Sultan?

[brak]

Tamie

Wampum

Geniuss:

(8-9)

$$
\text { i }
$$

Vom finkeluden Abendstern

Geniusz

VII. Przedwieczuych bngow moce

Tamże Wampum/Nuradin

(10-11) wtrạony do lochu

Szyldwachowie:

Wir singen, wir singen ans bähern Bafobl

VTII. Spiewajum, spienstimy za gornym rackazem /

Alan w

ogruxtrie
$(13-14)$

Alma

$$
\text { i }
$$

Geniusz

Geniuse Vow funtelonden Abendasern

IX. Przedwiecznych brogiw moca

(+ ujęla w recytatyw rozmowa z Alma)

Tamże Nurtadin z Almą̧

(15-16) pijątrucizne.

Wprowadrenic

Wampuma.

Grunot.

Tanzie Interwencia Geniusz:

(17 i ostamia) geniusea Thowheil der Serblichen

belachew

Końcowy chót 2 duetem Almy i Nuradina:

X. FINAL AKTU II

Lafit uns geviefor

Durch Scherz wnd Kuß 
Trzy numery solowe dodane przez Elsnera to arie Husseina (IV/I i II/II) oraz aria z recytatywem Nuradina (V/II). Dwa pierwsze (wraz z partiami z finałów) faktycznie tworzą partię wokalną Husseina, który w oryginale Kotzebuego miał jedynie kwestie mówione. Pierwsza aria („Ach ten królów król prawdziwy”) wywiedziona została z kwestii mówionej oryginału, w której Hussein na prośbę europejskiego lekarza wylicza gargantuiczny dzienny jadłospis sułtana. Druga („Wielbij wszystkie czyny Pana”) dodana została w miejscu, gdzie Alma przekonywana jest przez sułtańskiego sługę o niecelowości stawiania oporu; Hussein tłumaczy w niej, jak powinna zachowywać się w pałacu, by zyskać łaskę władcy. Poniżej podaję fragmenty polskiego i niemieckiego libretta dla drugiej z wymienionych arii; zestawienie to daje dobre pojęcie o dosłowności przekładu Bogusławskiego i Glińskiego, sposobie umieszczenia nowych numerów w libretcie oraz rodzaju i jakości dodanych fragmentów wierszowanych. Warto zwrócić uwagę na próbę ratowania dosłownego przekładu idiomatycznego zwrotu niemieckiego przez właściwie niepotrzebne dodanie przymiotnika („Die Zeit hat Flügel” - „Czas ma szybkie skrzydła”) ${ }^{30}$. Wzmianka o ogrodzie dodana pod koniec cytowanego fragmentu wynika ze zmian inscenizacyjnych: końcowe sceny warszawskiej adaptacji umieszczono przy altanie w ogrodzie, podczas gdy u Kotzebuego mają one miejsce przy komnacie Almy w pałacu.

Kotzebue

Am besten wirst du thun, gar nichts zu denken. Denn hier am Hofe wird viel geredet und nichts gedacht. -
Bogusławski/Gliński

Najlepiej zrobisz, kiedy wcale myśleć przestaniesz - bo u nas u dworu, wcale mówią a nic nie myślą - słuchaj, jak się u nas kierować trzeba, a upewniam, że wysoko staniesz:

[Aria, andante 3/4]

Wielbij wszystkie czyny Pana,

Mów, że w mocy jest Samsonem,

Że w mądrości Salomonem,

Padaj przed nim na kolana

A choć często jak człek zbłądzi,

Dziw się, że on jak Bóg rządzi;

[allegro $2 / 2$ ]

Gdy chcesz miejsca faworyty,

Wszystkie oczerniaj kobiety,

Wszystkich mężczyzn skarż, obwiniaj,

30 Szczątkowo zachowane polskie libretto (jak i niedostatek kompetencji literaturoznawczych autora) uniemożliwia pełną weryfikację zarzutów warszawskiego recenzenta w kwestii oddania przez tłumaczy „dowcipnej satyry oryginału”. Że nie zawsze starczyło im czasu lub umiejętności dla zajmowania się detalami, widać chociażby w braku jakiejkolwiek próby uratowania wspomnianej wyżej gry słów związanej z terminem „Aufklärung”: w polskiej wersji Hussein prosi „Gdyby twoja wysokość chciała się uniżyć aż do wyjaśnienia mi tej sprzecznej odpowiedzi”, trudno sobie wyobrazić jak miałaby wyglądać odpowiedź Wampuma zachowująca oryginalny dowcip. 
Plotek jak można przyczyniaj,

Umiej omdlewać, zapłakać,

Kiedy trzeba śpiewać, skakać,

Kręć się, podchlebiaj, wychwalaj,

To zagaś, to znów zapalaj,

Gdy potrafisz żądzę zrodzić,

Wszystkich będziesz za nos wodzić.

- Jetzt eile, wenn du Nurraddin retten willst. Die Zeit hat Flügel. Drei Stunden gab dir der Sultan Bedenkzeit. Du mußt einen Becher mit Sorbet zubereiten, eine Perle darin auflösen und ihm überreichen. Das ist das Zeichen der Unterwürfigkeit.
Teraz śpiesz, jeżeli chcesz uratować Nuradina. Czas ma szybkie skrzydła. Trzy godziny czasu dał ci sułtan do namysłu. Musisz pójść do ogrodu, przygotować puchar, sorbetem rozpuścić w nim perłę i ten sułtanowi ofiarować. To jest znakiem poddania się.

W podobny sposób wstawiono zapewne V numer II aktu (recytatyw: „Gdzież jestem? Widzę mury” - aria: „Ta piękność była dla mnie stworzona”) w monolog Nuradina na początku 4. sceny III aktu (w wersji Kotzebuego). Dodanie tej arii było chyba koniecznością przy transformacji singspielu w operę, zważywszy, że oryginał Kotzebuego nie przewidywał żadnego numeru solowego Nuradina - pierwszego tenora warszawskiej adaptacji. Dziwić należałoby się raczej, że pozostawiono głównego amanta opery bez arii w akcie pierwszym, oddając mu głos jedynie w duecie z Almą i finale.

Opuszczenie przez Elsnera jednego z trzech duetów szyldwachów trudno uważać za istotną ingerencję - jest to krótki dialog z trzywersową śpiewaną wspólnie konkluzją i wolno chyba się domyślać, że rozwinięcie go do rozmiarów odpowiadających choć z grubsza innym numerom wokalnym przyznawałoby zbyt już wiele miejsca w operze tym bądź co bądź pobocznym postaciom.

Szczegółowa i wyczerpująca analiza pozostających poza finałami numerów wokalnych opery Elsnera przekracza granice tej pracy. Uwagę z pewnością zwrócić warto na ich jednoznacznie operowy charakter, widoczny w stylu buffo partii komicznych, istotnym pierwiastku wokalnej wirtuozerii widocznym w koloraturach numerów solowych i duetów Almy, Nuradina i Geniusza, bogatej instrumentacji czy w rozbudowanych wstępach osiaggających nieraz rozpiętość pełnowymiarowych ritorneli. Większość numerów solowych zawiera powtórzenia dłuższych fragmentów tekstu „diese verdammte ewige Wiederhohlungen”, jak pisał Kotzebue we wstępie do innego libretta ${ }^{31}$ - ciążąc wyraźnie w stronę typowo operowych arii o strukturze binarnej, często ze zmianą tempa i metrum lub zmodyfikowanego da capo.

3I August von Kotzebue, Der blinde Gärtner, oder: die blühende Aloe. Ein Liederspiel, Kienreich I8II, s. 3. 
Cząstkowe spostrzeżenia Aliny Nowak-Romanowicz dotyczące wpływów włoskich $^{32}$ rozszerzyć można do generalnej tezy identyfikującej konwencje wiedeńskiej opery buffa i semiseria końca XVIII stulecia - zdefiniowane dziś nieporównywalnie lepiej niż przed półwiekiem - jako podstawowy kontekst interpretacyjny.

$\mathrm{Z}$ nieśpiewającej postaci Husseina wykreowano wiodącą rolę basso buffo caricato $^{33}$ o dwóch rozbudowanych, absolutnie typowych ariach ${ }^{34}$, z których pierwsza realizuje skonwencjonalizowany model ,arii katalogowej” znany nie tylko z mozartowskiego Don Giovanniego, lecz także np. z heroikomicznej opery Haydna Orlando Paladi$n o^{35}$ (obie te opery prowadził Elsner jako dyrygent teatru lwowskiego ${ }^{36}$ ). Drugorzędną partię buffo otrzymał Kaled - aria „Hopsa, hopsa, teraz żyć będę” osadzona jest $\mathrm{w}$ tymże idiomie wokalnym, choć ewidentnie z myślą o mniej wprawnym śpiewaku, wzbogacona za to rysem konwencjonalnej turecczyzny: janczarską hałaśliwością często akcentowanych, powtarzalnych komórek melodycznych (obiegniki), granych unisono przez instrumenty dęte z fletem piccolo, a także użyciem trójkąta i gran tamburo ${ }^{37}$. Charakter drugiego numeru Kaleda - narracyjnej romanzy przerywanej prozą pomiędzy strofami - wyznaczony został przez libretto, odwołuje się jednak do singspielowej konwencji wspólnej całemu obszarowi niemieckojęzycznemu, a znanej Elsnerowi chociażby z Uprowadzenia z seraju Mozarta ${ }^{38}$.

Mniej lub bardziej ewidentne motywy alla turca odnajdujemy również w motywice, rytmie i instrumentacji obu duetów szyldwachów, w pierwszym z nich komicznie zestawione z typowym dla opery buffa rysem muzycznej parodii: nienaturalność śpiewu przymuszonych do wokalnych popisów sułtańskich pachołków oddana jest odwołaniem do mocno już archaicznego ścisłego kontrapunktu.

Częściowy opis znaleźć można u Aliny Nowak-Romanowicz, Józef Elsner, op. cit., s. IO7-IIo.

3 Ów charakter głosu przypisany był do postaci służącego na mocy konwencji - szczególnie w operach orientalnych, jak świetnie Elsnerowi znane Uprowadzenie z seraju - i nie należy doszukiwać się efektu humorystycznego w fakcie, że śpiewa ją tu „dowódca czarnoskórych rzezańców sułtana”. Tego rodzaju skojarzenia prowadziłyby niebezpiecznie blisko jeszcze niedawno aktualnej kwestii prawdziwych kastratów operowych.

34 O wyznacznikach stylu buffo zob.: John Platoff, „The buffa aria in Mozart's Vienna”, Cambridge Opera Journal 2 (1990) nr 2, s. 99-I20. Dwie arie Husseina w podręcznikowy niemal sposób wykorzystują dwa typy materiału muzycznego arii buffo wyróżnione w artykule Platoffa.

35 Aria Pasqualego „Ho viaggiato in Francia, in Spagna”, zob.: Mary Hunter, „Text, music, and drama in Haydn's Italian opera arias: Four case studies”, The Journal of Musicology 7 (I989) nr I, s. 29-57; więcej o ariach „katalogowych” zob.: John Platoff, „Catalogue arias and the "Catalogue Aria”, w: Wolfgang Amadé Mozart: Essays on his life and his music, red. Stanley Sadie, Oxford 1996, s. 296-3II.

36 Zob.: Jerzy Got, Na wyspie Guaxary: Wojciech Bogustawski i teatr lwowski 1789-I799, Kraków I97I, s. 396.

37 Pokrewieństwo zasadniczej motywiki akompaniamentu arii z duetem Osmina i Pedrilla „Vivat Bachus” z Uprowadzenia z seraju - ustępem explicite alla turca - wydaje się oczywiste, a przy tym nieprzypadkowe, zważywszy na podobieństwo treściowe obu numerów. O osiemnastowiecznej „muzyce tureckiej” zob.: M. Hunter, „Alla Turca style”, op. cit.

38 Stąd najpewniej zaczerpnął tradycję Elsner, umieszczając narracyjną romanzę już w swojej pierwszej operze orientalnej Der verkleidete Sultan, zob.: A. Nowak-Romanowicz, Józef Elsner, op. cit., s. 40. O romanzy por. także: T. Bauman, op. cit., s. 34 . 

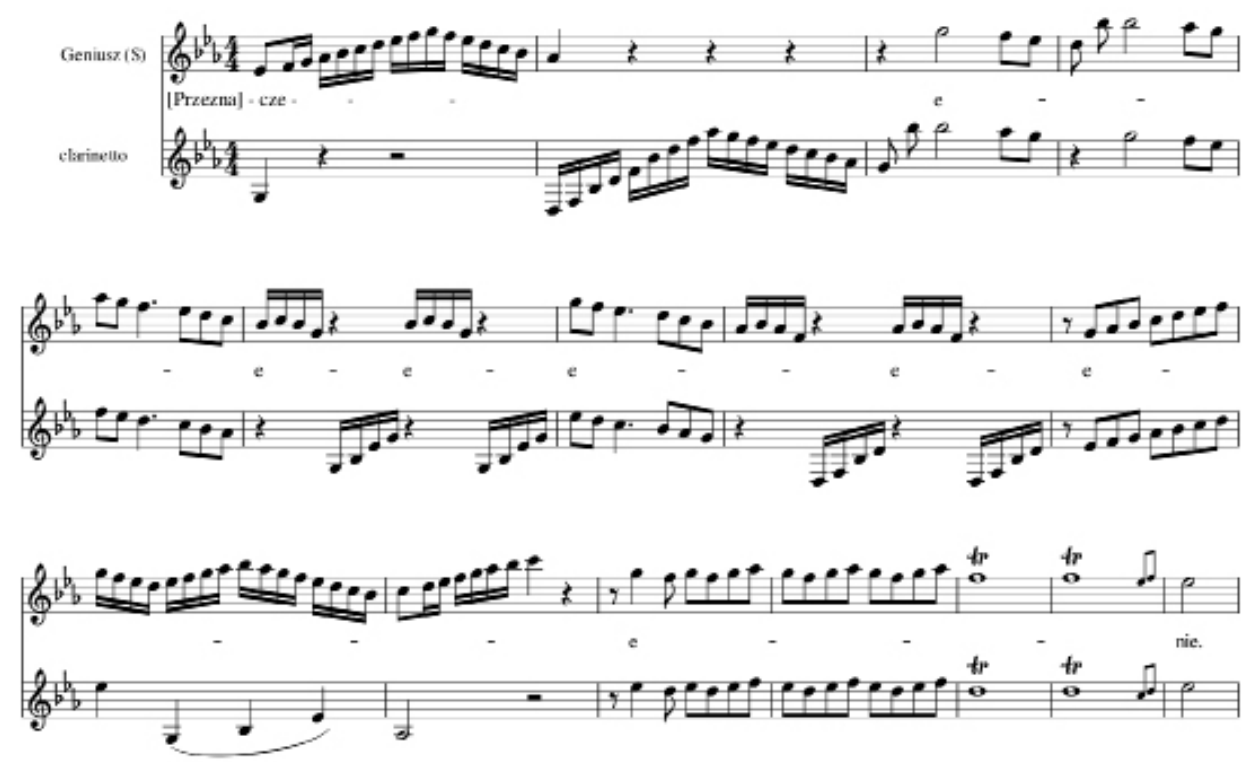

Przykł. I. Fragment arii Geniusza z finału II aktu (Allegro con brio), t. 24I-256.

Śpiew Nuradina i Almy utrzymany jest w stylu typowym dla mezzo carattere pogoldoniańskiej opery buffa - sentymentalnych kochanków wywodzących się ze średnich sfer społecznych, odznaczających się naturalnością i siłą uczucia z przewagą wdzięcznych, melodyjnych, raczej niedługich fraz zdobionych appoggiaturami i drobnymi biegnikami, często wieńczonych krótką koloraturą̧ $3^{39}$ Z poetyki tej w kierunku „stylu wysokiego” nieco wyłamuje się popisowy śpiew Almy przed Sułtanem („Sułtan jest słońca, jest słońca promykiem”), obfity w dłuższe koloratury, rozpoczęty zdecydowanie najdłuższym w operze, piętnastotaktowym ritornelem, co najciekawsze zaś, otwierający linię wokalną długimi wartościami zstępującymi z wysoka po kolejnych stopniach akordu - zabieg charakterystyczny raczej dla stylu serio, a będący niemal wizytówką heroicznych arii z elsnerowskich Amazonek. Z kolei nieobecna w oryginalnym libretcie aria Nuradina „Ta piękność była dla mnie stworzona” (po recytatywie „Gdzież jestem? Widzę mury...") to typowe (choć raczej skromne) rondò w dwóch tempach ${ }^{40}$, nieodzow-

39 O muzycznych wyznacznikach parti buffe, parti serie i sentymentalnych mezzo carattere zob.: Marita P. MacClymonds, „Opera buffa? Opera seria? Genre and style as sign”, w: Opera buffa in Mozart's Vienna, red. Mary Hunter i James Webster, Cambridge-New York 2000, s. 197-231; Mary Hunter, „The fusion and juxtaposition of genres in I770-I800: Anelli and Piccinni's "Griselda»", Music \& Letters 67 (I986) nr 4 , s. 363.

40 Don Neville, „Rondò”, w: Grove Music Online, https://doi.org/Io.IO93/gmo/9781561592630.article.23788, dostęp 2 X 2019. 
ny element wiedeńskiej opery buffa i semiseria lat osiemdziesiątych i dziewięćdziesiątych, w absolutnej zgodzie z konwencją wykorzystany dla ekspozycji kluczowego emocjonalnie momentu przejścia od rozpaczy bohatera (Larghetto) do decyzji o podjęciu działania (Allegro).

Dodajmy na koniec, iż dla quasi-instrumentalnej wirtuozerii koloratur finałowej arii Geniusza (zob. przykł. I. obok), prowadzonych w dialogu z klarnetem (instrument ten w czytelny sposób przypisany jest do postaci Geniusza na przestrzeni całej opery), trudno byłoby znaleźć inny pierwowzór niż partię Królowej Nocy z mozartowskiego Die Zauberföte - do wzorowania się na tym dziele przyznawał się Elsner wprost przy swym pierwszym singspielu4t a potem co najmniej kilkakrotnie prowadził jego lwowskie wystawienia ${ }^{42}$ (warszawski spektakl spolszczonej przez Bogusławskiego wersji dzieła miał pojawić się na afiszach dopiero dwa lata po Wampumie).

O ile umieszczenie w dziele numerów solowych czy duetów o stricte operowym charakterze trudno uznać za przesądzające o transformacji singspielu w operę komiczną z partiami mówionymi - szczególnie południowoniemiecki singspiel był pod tym względem dość elastyczny, a, jak już było wspomniane, struktura wersyfikacyjna libretta nie wskazuje na użycie typowo wodewilowych piosenek zwrotkowych - kierunek dokonanych przez Elsnera zmian wyraźniej sugerują sporadycznie pojawiające się recytatywy; głównie w partii Geniusza, lecz jeden raz także Nuradina. Co ważniejsze, dodane numery solowe łamią konsekwentnie budowaną przez Kotzebuego konwencję umieszczania śpiewu jedynie tam, gdzie pojawia się on rzeczywiście jako element świata przedstawionego - najdrastyczniej chyba w przypadku arii z recytatywem Nuradina rozpaczającego po uprowadzeniu Almy.

Tym jednak, co ostatecznie rozstrzyga o tożsamości gatunkowej polskiej adaptacji, stanowiąc zarazem największą ingerencję warszawskiego zespołu w utwór niemieckiego dramatopisarza i zadając decydujący cios wspomnianej wyżej konsekwentnej „tematyzacji” śpiewu, są wieloodcinkowe finały, w których samo następstwo zdarzeń zostaje ujęte i wyartykułowane muzycznie. Trudno też wątpić w to, że właśnie ich użycie przesądziło o zmianie struktury aktowej dramatu, której głównym celem miało być najpewniej zbudowanie efektownego muzycznie i dramatycznie finału pierwszego aktu wokół sceny porwania Almy z domu Nuradina. Tym sposobem utwór Bogusławskiego i Elsnera realizuje jeden $z$ bardziej typowych modeli strukturalnych opery buffa końca XVIII w. - dwuaktowy, z centralną kulminacją w pierwszym finale, który pozostawia

4I A. Nowak-Romanowicz, Józef Elsner, op. cit., s. 39.

42 J. Elsner, op. cit., s. 98. 
akcję w swoistym zawieszeniu ${ }^{43}$. W świetle tej modyfikacji wyraźniej wyodrębnia się jeszcze jedna ciekawa cecha oryginału Kotzebuego: niemiecki dramatopisarz zamyka dwa pierwsze akty scenami niezwiązanymi bezpośrednio z głównym wątkiem Nuradina i Almy, pozostawiając widzów po opadnięciu kurtyny z komicznymi obrazami zaśnięcia sułtana (akt I) i groteskowej śpiewki Kaleda (akt II) - jakby mniej zależało mu na budowaniu narracyjnego napięcia, a bardziej na retardacji akcji osiagniętej poprzez rozpraszanie uwagi widzów na komiczne wątki poboczne.

Struktura finału pierwszego aktu przedstawia się następująco:

\begin{tabular}{|c|c|c|c|c|c|c|c|}
\hline & odcinek & osoby & akcja & takty & tonacja & $\begin{array}{l}\text { tempo, } \\
\text { metrum }\end{array}$ & charakter \\
\hline I. & $\begin{array}{l}\text { "O, ty duszo } \\
\text { mej istności" }\end{array}$ & $\begin{array}{l}\text { Nuradin, } \\
\text { Alma, } \\
\text { Hussein, } \\
\text { Kaled }\end{array}$ & $\begin{array}{c}\text { Rozmowa } \\
\text { Almy } \\
\text { i Nuradina, } \\
\text { wejście Kaleda } \\
\text { z Husseinem }\end{array}$ & $\mathrm{I}-7 \mathrm{O}$ & $G$-dur & $\begin{array}{c}\text { Larghettto } \\
2 / 4\end{array}$ & $\mathrm{E}(\rightarrow \mathrm{A})$ \\
\hline 2. & $\begin{array}{c}\text { "Co tu chcesz, } \\
\text { przeklęty" }\end{array}$ & jw. & $\begin{array}{c}\text { Nuradin } \\
\text { zauważa } \\
\text { Kaleda }\end{array}$ & $7 \mathrm{I}-\mathrm{I} 43$ & $G$-dur & $\begin{array}{c}\text { Allegro } \\
3 / 4\end{array}$ & A \\
\hline 3. & $\begin{array}{l}\text { „Ach, co ja } \\
\text { czytam” }\end{array}$ & jw. & $\begin{array}{c}\text { Nuradin } \\
\text { czyta rozkaz } \\
\text { Wampuma }\end{array}$ & $\mathrm{I} 44-25 \mathrm{I}$ & $\begin{array}{c}G-d u r \rightarrow \\
g-m o l l \rightarrow \\
\quad E s-d u r\end{array}$ & $\begin{array}{c}\text { Moderato } \\
2 / 2\end{array}$ & $\mathrm{E}(\rightarrow \mathrm{A})$ \\
\hline 4. & $\begin{array}{c}\text { "Więc umieraj, } \\
\text { ty poczwaro" }\end{array}$ & $\begin{array}{c}\text { jw., } \\
\text { janczarzy } \\
\text { (chór) }\end{array}$ & $\begin{array}{c}\text { Nuradin rzuca } \\
\text { się na Kaleda } \\
\text { ze sztyletem, } \\
\text { wchodzą } \\
\text { janczarzy } \\
\text { i porywają } \\
\text { Almę }\end{array}$ & $252-333$ & $E s-d u r$ & $\begin{array}{c}\text { Allegro assai } \\
2 / 2\end{array}$ & A \\
\hline 5. & $\begin{array}{c}\text { „Almo, już cie } \\
\text { nie zobaczę” }\end{array}$ & $\begin{array}{c}\text { Nuradin, } \\
\text { Alma, } \\
\text { "chór na } \\
\text { teatrze”, „,chór } \\
\text { za teatrem” }\end{array}$ & $\begin{array}{c}\text { Janczarzy } \\
\text { odchodzą, } \\
\text { zabierając } \\
\text { Almę }\end{array}$ & $334-376$ & jw. & jw. & E \\
\hline
\end{tabular}

43 Zob. np. Alfred Einstein, Mozart. Cztowiek i dzieto, Kraków I983, s. 4II, także: Piero Weiss, „Opera buffa. 4. The later I8th century”, w: The New Grove dictionary of music and musicians wyd. 2, op. cit., https:// doi.org/IO.I093/gmo/9781561592630.article.4372I, dostęp 29 IV 2019. 
Najciekawszy muzycznie jest otwierający finał kwartet, chwalony przez recenzentów za „uczoność” i „wdzięk”. Głównym pomysłem konstrukcyjnym i dramatycznym jest nałożenie na siebie dwóch par głosów o przeciwstawnym charakterze. Na tle lekkiego, pogodnego akompaniamentu granego przez smyczki pizzicato i szesnastkowych figuracji altówek Alma z Nuradinem śpiewają o swojej miłości:

Nuradin

O, ty duszo mej istności, ty mojego szczęścia źródło,

Bóstwo prawdziwej miłości w moje ręce cię przywiodło.

Alma

Sam zapewne prorok Mekki dał mi poznać cię, mój luby,

Chciał, znać, serca te na wieki przez najmilsze spoić śluby.

Razem

Nie chcąc bogactw królom danych, gardzę sułtana serajem,

Dla serc szczerze rozkochanych miłość jest prawdziwym rajem.

Jednak na dłuższe, lekkie, zdobione delikatnymi fioriturami i harmonijnie rozwijające się frazy zaczynają po chwili nakładać się groteskowo krótkie, utrzymane w manierze buffo kwestie sług sułtana (zob. przykł. 2 poniżej):

Kaled

Patrzaj, oto są oboje!

Hussein

Nieszpetne jakieś stworzenie!

Kaled

Przystąp ty, bo ja się boję!

Hussein

Ty masz sułtana zlecenie!

Kaled

Czegoż próżno się lękamy!

Hussein

Wszak janczarów z sobą mamy!

W dalszym ciągu odcinka Nuradin i Alma, jakby nie słysząc przybyłych, przysięgają sobie wierność, co Hussein i Kaled kwitują złośliwymi uwagami. Spostrzeżenie przybyszów przez Nuradina („Co tu chcesz, przeklęty?”) otwiera drugi odcinek finału (Allegro, 2/2), w którym smyczki podejmują unisono wzburzoną motywikę szesnastkową. Antyfonalnie rozpisany spór kończy się żądaniem przedstawienia sułtańskiego rozkazu. Kolejne ogniwo istotnie zwalnia tempo, wprowadzając niepokojący, powolny rytm synkop i modulując do tonacji $g$-moll - materiał ów przewidziany jest jako tło dla czytania rozkazu przez Nuradina, a potem opadających szerokimi łukami kwestii zrozpaczonych Nuradina i Almy. Decyzja ucieczki, 

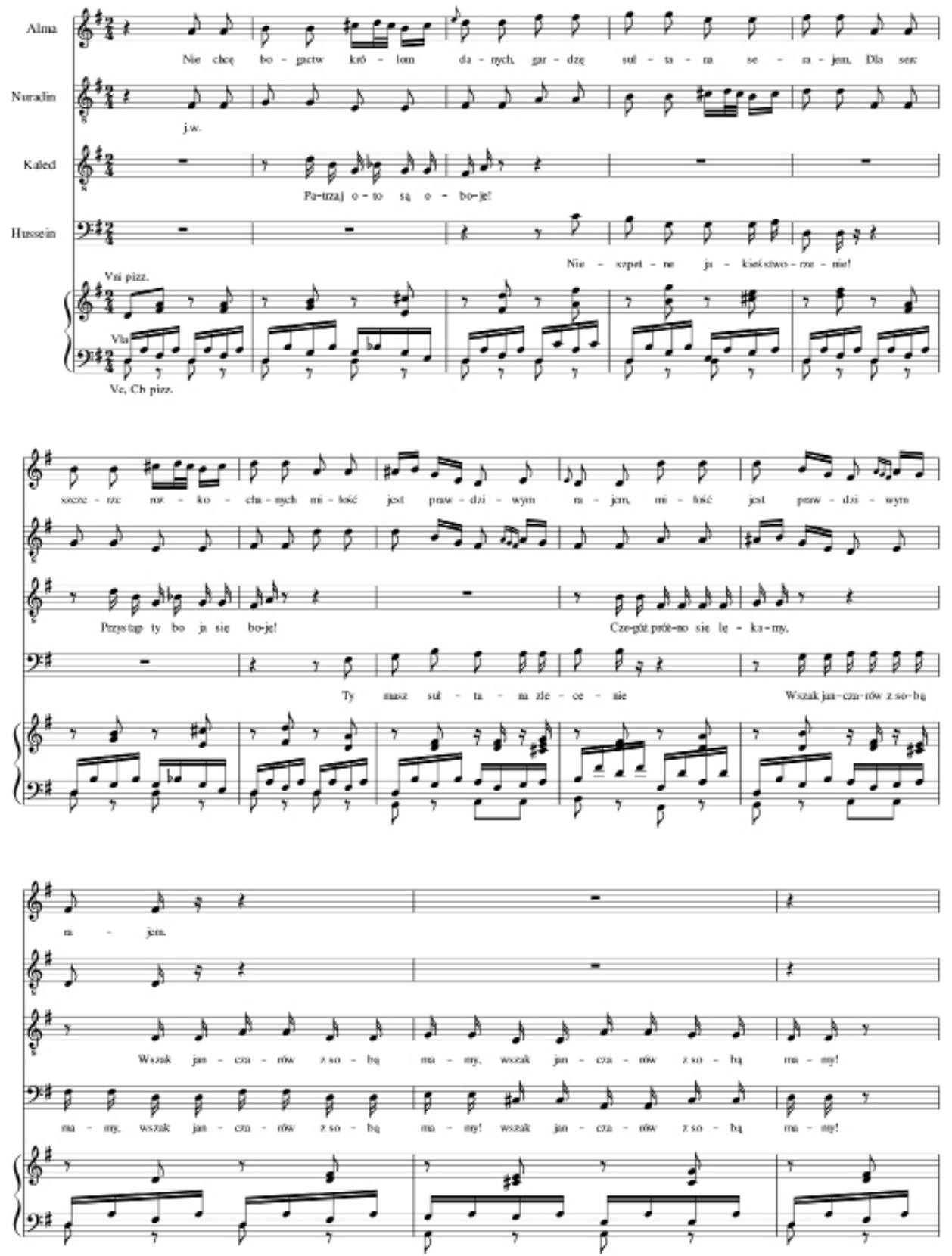

Przykł. 2. Fragment pierwszego ogniwa finału I aktu (Larghetto), t. 26-38. 
której na przeszkodzie stoi obecność Kaleda, prowadzi do stanowiącego kulminację ogniwa czwartego: batalistyczne motywy smyczków unisono towarzyszą heroicznej melodyce gróźb rzucającego się na byłego sługę ze sztyletem Nuradina, z kolei chóralny śpiew wchodzących janczarów („Słuchajcie woli sułtana!”) utrzymany jest w cyklicznym następstwie chromatycznych połączeń akordów. Ostatnie ogniwo zachowuje metrum i tempo poprzedniego, gaśnie jednak dynamicznie - muzyka brzmi coraz ciszej, Almę i część janczarów słychać zza sceny, Nuradin lamentuje i traci przytomność.

Wyraziste różnicowanie za pomocą środków muzycznych charakteru postaci śpiewających razem w otwierającym finał kwartecie czyni go unikatowym wśród operowych ansambli Elsnera - efektownie splatając ze sobą typ wokalistyki właściwy postaciom komicznym i sentymentalnym mezzo carattere, staje kompozytor na poziomie czołowych współczesnych mu wiedeńskich twórców operowych. Choć kolejne odcinki nie mają już tego polotu - w sekcjach 2. i 4. toczący ze sobą wzburzony dialog Kaled i Nuradin posługują się tymi samymi zwrotami melodycznymi, a struktury tworzone przez nakładające się głosy czworga postaci nie osiągają już podobnej jak w pierwszym odcinku złożoności - środki muzyczne użyte są do artykulacji dramaturgii finału sprawnie i skutecznie.

Przebieg finału buffo opisuje się często, wedle koncepcji Johna Platoffa, jako regulowany następstwem odcinków akcji i ekspresji ${ }^{44}$. Charakter ów wyszczególniono w ostatniej kolumnie powyżzzego zestawienia (odpowiednio literami A i E; zob. s. 22); w omawianym przypadku podział ów, jak zaznaczono w tabeli, nie jest całkowicie ostry: odcinki ekspresywne, poza ostatnim, nabierają stopniowo cech aktywności, ciążąc w stronę kolejnych ogniw finału. Początkowy duet miłosny pojawia się w naturalny sposób (trudno wyobrazić sobie inne rozwiązanie, można więc uznać to za pewnik) jako ekspresyjne dopełnienie rozmowy Nuradina i Almy w 4. scenie oryginału, jednak nadejście Husseina z Kaledem nadaje mu charakter na poły aktywny, choć rosnące napięcie wyładowuje się dopiero z momentem spostrzeżenia przybyszy przez Nuradina, a więc z początkiem kolejnego ogniwa. Podobnie rozwija się odcinek trzeci, ewoluując od rozpaczy Nuradina po przeczytaniu rozkazu aż do ataku na Kaleda. Symetria pomiędzy odcinkami 2. i 4. idzie zresztą głębiej: oba rozpoczynają się wejściem smyczków w unisonie i wzburzonym, silnie nacechowanym ekspresyjnie rysunkiem partii wokalnej. Oba też swą wewnętrzną strukturą odbijają w miniaturze typową tendencję rozwojową finału buffo, przechodząc od dialogu pojedynczych postaci, przez wymianę kwestii śpiewanych parami, aż do końcowej niby-stretty, w której wszyscy obecni śpiewają jednocześnie. Innym udanym rysem architektonicznym jest centralna modulacja z $G$-dur do g-moll/Es-dur w odcinku trzecim, odpowiadająca

44 John Platoff, „Musical and dramatic structure in the opera buffa finale”, The Journal of Musicology 7 (I989) nr 2, s. 193-I94. 
decydującemu o kierunku akcji momentowi ujawnienia rozkazu sułtana i utracie nadziei przez Nuradina i Almę.

Wyraziste zróżnicowanie materiału muzycznego pięciu ogniw zbalansowane jest elementami łączącymi: pod koniec pierwszego ogniwa w smyczkach pojawiają się już charakterystyczne motywy kolejnego, przejście od trzeciego do czwartego wyartykułowane jest jako kulminacja uporczywych motywów rytmicznych drewna pojawiających się i stopniowo rosnących w siłę w końcowej fazie odcinka poprzedzającego, a podjętych ostatecznie przez smyczki unisono w otwarciu batalistycznego allegro assai; ostatnie ogniwo wreszcie zręcznie łączy stopniowo gasnącą tęże motywikę z reminiscencjami powolnych synkop ekspresyjnego ogniwa trzeciego.

Budowa finału zarówno w całości, jak i w szczegółach, zdaje się potwierdzać formułowaną przez Alinę Nowak-Romanowicz opinię, że do rozwiązań konstrukcyjnych już w swej wczesnej twórczości miał Elsner rękę szczególnie szczęśliwą ${ }^{45}$. Muzyka, ściśle przylegając do przebiegu zdarzeń, ewoluuje od początkowej lekkości stylu buffo, przez heroiczne wzburzenie, aż do końcowej rezygnacji. Treściowo finał Elsnera, Bogusławskiego i Glińskiego nie gubi zasadniczo nic z zawartości niemieckiego oryginału: mamy tutaj początkowe oburzenie pewnego siebie - bo nieświadomego sułtańskiego rozkazu - Nuradina, próbę przekupienia Kaleda, decyzję ucieczki i końcową rozpacz bohatera. Nie ominięto nawet oryginalnych detali komicznych, jak wyzwisko „pawian”, którym obdarzył Kaleda na początku sztuki Nuradin, co wciąż jest mu przez byłego sługę wypominane. Dodany w warszawskiej adaptacji koncept nałożenia na siebie miłosnego duetu pary głównych bohaterów z groteskowym dialogiem niezauważonych z początku Husseina i Kaleda jako pomysł dramatyczny zasługuje na ocenę nie mniej wysoką niż jego muzyczna realizacja.

O ile jednak finał pierwszego aktu ocenić wypada wysoko, jako artykułujący środkami muzycznymi sam przebieg akcji, ze szczególnym uwzględnieniem zachodzących pomiędzy osobami dramatu dramatycznych interakcji umuzycznionych jako fragmenty ansamblowe lub ansamblowo-chóralne, finał aktu drugiego wypada na tym tle już nieco mniej korzystnie. Obejmuje on ostatnią scenę, począwszy od grzmotu zwiastującego pojawienie się Geniusza. Składa się z trzynastu (niekiedy bardzo krótkich) sekcji muzycznych, które pogrupować można zasadniczo na trzy kategorie: I) fragmenty chóralne, mające charakter eksklamacyjnych komentarzy do zachodzących wydarzeń, 2) fragmenty dialogowe zawierające główną akcję dramatu, ujęte w formę recytatywu accompagnato (Geniusz) łączonego z „melodramą”, to jest mówionymi kwestiami wplecionych w tkankę muzyczną (Wampum), 3) pełnoprawne solowe lub ansamblowe numery wokalne: aria Geniusza, tercet, końcowy śpiew Wampuma.

Już z pobieżnego opisu widać więc wyraźnie, że trudno mówić tu o substancjalnie muzycznym ujęciu dramatycznej akcji - można by wręcz powiedzieć, że zdobycze

A. Nowak-Romanowicz, Józef Elsner, op. cit., s. 64. 
osiemnastowiecznej opery buffa w tym zakresie zostają zignorowane i powracamy do mocno już w czasach Elsnera archaicznego modelu akcji posuwającej się naprzód jedynie w recytatywach. Atrakcyjność finału zostaje sztucznie podreperowana dodaniem nieobecnych u Kotzebuego (i z dramatycznego punktu widzenia niewiele wnoszących) komentarzy chóru, sporadycznie tylko wzbogacanych elementami dramatycznymi - jak w odcinku szóstym, gdy Geniusz skazuje Kaleda na chłostę, skazany prosi o łaskę, zaś chór ochoczo podejmuje sentencję wyroku. Swoje znaczenie mają także efektowne numery wokalne: polonezowe trio Geniusza i dziękującej mu za ratunek pary kochanków, przede wszystkim zaś wokalne tour de force opery: brawurowa „aria z morałem” „Tu i oraz wszędzie” (Allegro assai) ze współzawodnictwem zawrotnych koloratur Geniusza i wirtuozowskich figuracji klarnetu (instrument ten w czytelny sposób przypisany jest do postaci Geniusza w toku całej opery). Można wskazać i na zalety samej konstrukcji finału, spajanej powracającym materiałem muzycznym partii chóralnych czy też fragmentów związanych z Geniuszem - ogółem jednak muzyczna sugestywność finału jako całości pozostaje, jako się rzekło, zewnętrznym dodatkiem, niezwiązanym substancjalnie z kształtem akcji dramatu.

Konstatacji tej nie należy rozumieć jako zarzutu względem warsztatu kompozytora. Ujęta $\mathrm{w}$ finał scena zawiera ostateczne rozwiązanie intrygi na zasadzie nieco komicznego deus ex machina: Geniusz objawia się, odwraca działanie pierścieni i trucizny, po czym ogłasza swoje wyroki i pouczenia; próby sprzeciwu Wampuma zostają zduszone w zarodku. Nie ma już dramaturgicznego napięcia pomiędzy postaciami ani istotnych zwrotów akcji. Patrząc nieco szerzej, zakwestionować można by więc raczej samo rozplanowanie finału w obrębie oryginalnego libretta. Efektowność finałów buffo zasadza się na muzycznej artykulacji nabierającego tempa toku akcji, zaskakujących, choć wszak przewidywalnych konsekwencji wcześniejszych wydarzeń i decyzji, pojawiania się kolejnych postaci, komicznych omyłek, scen rozpoznania, qui pro quo i tym podobnych, zasadniczo skonwencjonalizowanych chwytów dramatycznych ${ }^{46}$; odpowiadającą tej charakterystyce partię Wampuma odnajdujemy w libretcie nieco wcześniej, gdy ujawniają się komicznie (przynajmniej z punktu widzenia widowni), opaczne skutki urzeczywistnionych życzeń trojga bohaterów, kulminując ostatecznie w momencie spotkania Wampuma w postaci Nuradina z Nuradinem w postaci Wampuma. Można by więc zaryzykować stwierdzenie, że muzyczny finał Elsnera zaczyna się za późn o, by miał szanse zaistnieć jako prawdziwy finał buffo ${ }^{47}$.

46 Por.: J. Platoff, „Musical and Dramatic Structure”, op. cit., s. 197.

47 Nie chciałbym wprost postulować, że zakończenie dramatu Kotzebuego, samo w sobie mające coś z lakoniczności, pozwalałoby w ogóle na skonstruowanie efektownego finału. Warto zresztą przypomnieć, że w operach Mozarta - świetnie Elsnerowi znanych i stanowiących dla niego istotny punkt odniesienia, szczególnie na początku jego twórczości operowej - to pierwszy finał opery był tym „najbardziej złożonym i najbłyskotliwszym”, zob.: Charles Rosen, Styl klasyczny. Haydn, Mozart, Beethoven, przekł. Rafał Augustyn, Kraków 20I4, s. 369. 


\section{Wykaz skrótów}

W. - Wampum

N. - Nuradin

mel. - melodram

\begin{tabular}{|c|c|c|c|c|c|c|}
\hline & sekcja & osoby & akcja & takty & tonacja & $\begin{array}{l}\text { tempo, } \\
\text { metrum }\end{array}$ \\
\hline I. & $\begin{array}{c}\text { „Proroku! } \\
\text { Proroku } \\
\text { Mahomecie!” }\end{array}$ & Chór, Alma & Grzmot & $\mathrm{I}-43$ & $c$-moll & $\begin{array}{c}\text { Allegro } \\
2 / 2\end{array}$ \\
\hline 2. & $\begin{array}{l}\text { "Ja, który } \\
\text { nigdy nie } \\
\text { błądzę" }\end{array}$ & $\begin{array}{c}\text { Geniusz, } \\
\text { Wampum } \\
\text { (melodrama) }\end{array}$ & $\begin{array}{c}\text { Przywrócenie } \\
\text { postaci } \\
\text { W. i N. }\end{array}$ & $44-68$ & - & Recitativo \\
\hline 3. & „Co za cud” & $\begin{array}{c}\text { Chór, Alma } \\
\text { Kaled, } \\
\text { Hussein }\end{array}$ & - & $69-87$ & $E s$-dur & \\
\hline 4. & $\begin{array}{l}\text { „Dzięki Bogu, } \\
\text { że znowu } \\
\text { powracam do } \\
\text { brzucha” }\end{array}$ & $\begin{array}{l}\text { Wampum } \\
\text { (mel.) }\end{array}$ & - & $88-90$ & - & Come recitativo \\
\hline 5. & $\begin{array}{c}\text { „Przez moc } \\
\text { dzielną tego } \\
\text { ducha” }\end{array}$ & $\begin{array}{l}\text { Nuradin, } \\
\text { Alma, } \\
\text { Geniusz }\end{array}$ & - & $9 \mathrm{I}-\mathrm{I} 35$ & $G$-dur & $\begin{array}{l}\text { Alla Polacca } \\
\text { moderato con } \\
\text { Andantino }\end{array}$ \\
\hline 6. & $\begin{array}{c}\text { "A poku }{ }^{48} \text { tego } \\
\text { będzie?”" }\end{array}$ & $\begin{array}{l}\text { Wampum } \\
\text { (mel.), } \\
\text { Geniusz }\end{array}$ & $\begin{array}{c}\text { Sprzeciw } \\
\text { Wampuma, } \\
\text { groźba Geniusza }\end{array}$ & $\mathrm{I} 36-\mathrm{I} 4 \mathrm{I}$ & - & $\begin{array}{l}\text { Tempo Imo come } \\
\text { recitativo }\end{array}$ \\
\hline 7 & „Ach! Stój!” & $\begin{array}{c}\text { Chór, Kaled, } \\
\text { Geniusz }\end{array}$ & $\begin{array}{l}\text { Kaled wzywa } \\
\text { straż, Geniusz } \\
\text { skazuje go } \\
\text { na chłostę }\end{array}$ & $\mathrm{I} 42-\mathrm{I} 76$ & c-moll & A tempo Allegro \\
\hline 8. & $\begin{array}{c}\text { „Ale to jest } \\
\text { rzecz dziwna!” }\end{array}$ & $\begin{array}{l}\text { Wampum } \\
\text { (mel.) }\end{array}$ & $\begin{array}{l}\text { Powtórny } \\
\text { sprzeciw } \\
\text { Wampuma }\end{array}$ & $\mathrm{I} 77-\mathrm{I} 8 \mathrm{O}$ & - & Come recitativo \\
\hline 9. & $\begin{array}{l}\text { „Tu i oraz } \\
\text { wszędzie” }\end{array}$ & Geniusz & $\begin{array}{c}\text { Pouczenie } \\
\text { Geniusza } \\
\text { i jego zniknięcie }\end{array}$ & I8I-268 & Es-dur & Allegro con brio \\
\hline
\end{tabular}

48 Zagadkowe słowo „poku” - najpewniej forma „póki”, nieobecna w dziewiętnastowiecznych (i późniejszych) słownikach polskich - wykaligrafowane jest w partyturze z czytelnością wykluczającą wszelkie wątpliwości. Być może użycie nieliterackiej (może potocznej czy gwarowej?) wersji słowa pełnić miało funkcję efektu komicznego. 


\begin{tabular}{|c|c|c|c|c|c|}
\hline IO. & $\begin{array}{c}\text { „Co za dziw! } \\
\text { Ledwo kto } \\
\text { zoczył...” }\end{array}$ & Chór & $269-275$ & Es-dur & jw. \\
\hline II. & $\begin{array}{l}\text { „Dobrze } \\
\text { zrobił, że } \\
\text { poszedł” }\end{array}$ & $\begin{array}{l}\text { Wampum } \\
\text { (mel.) }\end{array}$ & $276-286$ & - & Come recitativo \\
\hline I2. & $\begin{array}{l}\text { „Że tak } \\
\text { śpiewacie } \\
\text { pięknie” }\end{array}$ & \begin{tabular}{|c|} 
Wampum \\
(pierwszy \\
raz śpiewa), \\
Hussein, Chór
\end{tabular} & $287-306$ & $C-d u r$ & Andantino \\
\hline
\end{tabular}

Jak było już wspomniane (widać to również w powyższej tabeli), samo zakończenie warszawskiej adaptacji istotnie odbiega od libretta Kotzebuego. Zrezygnowano ze sceny zaśnięcia Wampuma, zastępując ją akcentem istotnie odmiennym - jest to najbardziej zdumiewająca ingerencja polskich adaptatorów w dramat Kotzebuego, nie bez polotu wszakże rozwijająca istotny wątek oryginału. Po zniknięciu Geniusza ${ }^{49}$ i odpowiednim komentarzu chóru („Co za dziw! Ledwo kto zoczył, / jak się w drzewo przeistoczył!") Wampum - jak było wspomniane, jedyna nieśpiewająca postać pośród głównych bohaterów opery - wygłasza zaskakującą pochwałę Geniusza za podporządkowanie się jego rozkazowi: „Dobrze zrobił, że poszedł, bo jużem się gniewał, / jednak za to go lubię, że ferman ${ }^{\text {so }}$ szanuje, bo nic nie gadał, lecz śpiewał” - po czym ogłasza, iż odtąd sam zacznie śpiewać, rozpoczynając końcową, pastoralnie rozkołysaną arię (Andantino, I2/8), w której tak oto zwraca się do pary kochanków:

Że tak śpiewacie pięknie,

Aż serce we mnie mięknie,

Więc was śpiewając łączę,

Śpiewając wszystko kończę. ${ }^{\text {.I }}$

49 W adaptacji Bogusławskiego i Elsnera zamienia się on w drzewo (tak zanotowano w partyturze) - trudno powiedzieć, czy miało za tym kryć się jakieś dodatkowe znaczenie, czy wynikło to z przeniesienia ostatniej sceny do ogrodu, czy też może istniały jakieś techniczne problemy z zainscenizowaniem zniknięcia.

so Ferman, częściej firman - w dawnych państwach muzułmańskich specjalny, osobisty rozkaz sułtana wydany na piśmie.

5I Partytura zawiera tu dość zagadkową niejasność: w krótkim wstępie do arii Wampuma, wprowadzającym pierwszą frazę melodii partii wokalnej, wpisane są także partie Almy i Nuradina, dwojące melodie pierwszych i drugich skrzypiec (w tym drugim przypadku oktawę niżej), jednakże bez podanego tekstu. Prawdopodobieństwo, że brak tekstu wynikał z niedopatrzenia, wydaje się raczej niewielkie, jako że partytura była w użytku przez wiele lat i sporządzono ją bardzo starannie, jeszcze mniej prawdopodobna jest pomyłka kopisty (tj. Elsnera) w identyfikacji pięciolinii, jako że partie poprawnie zanotowano w kluczach sopranowym i tenorowym. Przypuszczenie, że była tu przewidziana wokaliza bez tekstu, odpowiadałoby teoretycznie wygłaszanej przez Wampuma pochwale śpiewu pary bohaterów, jednak z równym albo i większym sensem może się ona odnosić do wcześniejszych partii wokalnych Nuradina i Almy, zaś rozpoczęcie śpiewu przez parę kochanków pomiędzy wygłoszoną prozą zapowiedzią śpiewu Sułtana a samą arią wydaje się - z dramatycznego punktu widzenia - mało uzasadnione. 
Możemy dziś sobie tylko wyobrażać, jaki efekt wywoływać musiał w warszawskim teatrze ograniczony umysłowo satrapa, żarłok i okrutnik - odgrywany zapewne nader celnie i błyskotliwie przez niezrównanego komika Alojzego Żółkowskiego gdy znienacka zaczynał śpiewać te słowa, nie najszpetniejszym zapewne barytonem, na sielankową, pastoralnie rozkołysaną nutę... Na tym jednak nie koniec, Gliński z Bogusławskim postanowili bowiem zamknąć sztukę akcentem zdecydowanie ludycznym. W dalszym ciągu arii Sułtan zastanawia się, czy mógłby teraz wyrazić swoje życzenie śpiewem i pyta Husseina, czy odgaduje może, czego sobie życzy, trafna zaś odpowiedź podjęta zostaje w końcowym chórze do słów: „Pieczenia, hej pieczenia, niechaj się przyrumienia!", na którego tle Hussein proponuje sułtanowi coraz to inne potrawy, władca zaś niezmiennie obstaje przy swym pierwszym wyborze. W drugiej części chóru na tle słów o pieczeni Nuradin z Almą dośpiewują do rymu: „O słodkie przeznaczenia, los nasz miłość odmienia”.

\section{PODSUMOWANIE}

Dziełko Kotzebuego przy swoim dość niewielkim ciężarze gatunkowym ma jednakże kilka cech oryginalnych i na swój sposób ujmujących: uczynienie śpiewu jednym ze swoich tematów podparte konsekwentnym jego użyciem jedynie tam, gdzie rzeczywiście ma on pojawić się wewnątrz świata przedstawianego, zakamuflowane szczęśliwym zakończeniem fatalistyczno-sceptyczne przesłanie komedii, które zdaje się w jakiś osobliwy sposób korespondować z cyrkularnym zamknięciem sztuki powtórką zaśnięcia sułtana z końca aktu I, wreszcie nie najpośledniejszego gatunku walory komiczne, użyte zasadniczo jako zjadliwa krytyka despotyzmu władzy absolutnej. Każda z tych cech - jak i wspomniana wcześniej oryginalna struktura aktowa, eksponująca poboczne wątki komiczne kosztem głównej intrygi - na swój sposób dystansuje się od dominującego w środowisku Elsnera pojęcia czarodziejskiej opery komicznej jako popularnej rozrywki przeznaczonej dla niewybrednej raczej publiczności - sztuki wyczerpującej się w pasjonującej intrydze, atrakcyjnym dla szerokich mas dowcipie, możliwie sugestywnej szacie muzycznej i elementach wielkiego widowiska - razem wzięte zaś mogłyby wskazywać na przedstawienie raczej powściągliwe w muzycznej formie i przeznaczone dla nie najmniej wyrafinowanej widowni.

Tercet warszawskich adaptatorów miał ewidentnie inne zamiary. Konwencja prezentowania śpiewu jako elementu świata przedstawionego została przełamana, by zaopatrzyć dzieło w oprawę pełnowartościowej opery komicznej, co nie przeszkodziło jednak w podjęciu obecnego w oryginalnym libretcie „wątku śpiewaczego”, a nawet w twórczym wzbogaceniu go o końcową, zaskakującą ,arię" dotąd niemuzykalnego Wampuma. „Muzyczne nawrócenie” despoty zastępujące oryginalną scenę zaśnięcia, pozwoliło zbudować huczne, jednoznaczne i pozbawione dwuznaczności szczęśliwe zakończenie; w jego ludycznym zgiełku ginie jednakże niepokojące przesłanie Geniu- 
sza. Że oświeceniowy optymizm warszawskich twórców miał z nim niejaki kłopot, widać także w szczegółach - gdzie indziej niemal dosłownego - przekładu libretta: w polskiej wersji finałowej arii Geniusz śpiewa „Nie życzcie! nie żądajcie! ...niebacznie" 52 - przy czym ostatnie słowo, podkreślone opadającym melizmatem, nabiera wyraźnego charakteru dopełniającej znaczenie wersu pointy, podczas gdy w oryginale zamiast owego dopowiedzenia widnieje po prostu dosadne „ihr Thoren!” („wy głupcy!”). Podczas gdy libretto Kotzebuego nieprawdopodobnym następstwem wydarzeń wykazać ma bezcelowość wszelkich człowieczych starań rozumowego zapanowania nad swym losem, modyfikacja przyjęta w warszawskiej adaptacji zdaje się sugerować, że bohaterowie zawinili jedynie brakiem dostatecznej roztropności. Tę samą intencję złagodzenia sceptycznej wymowy sztuki widać w adaptacji drugiej części tytułu, w oryginale brzmiącego po prostu „die Wünsche”, po polsku zaś - „Nieroztropne życzenie”. Oba wymienione elementy przekładu, wbrew intencjom autora, odejmują radykalnie sceptyczne ostrze jednoznacznemu „morałowi” sztuki, nie dbając zresztą o spójność wprowadzanych modyfikacji z pozostawioną bez zmian intrygą.

Reprezentujący warszawskich Iksów recenzent wprost zganił dwa spośród dodanych fragmentów muzycznych: "gastronomiczną" arię Husseina i jego dialog z Wampumem na końcu sztuki (z pewnością chodziło tu o końcowy śpiew o przyrumieniającej się pieczeni). Nietrudno pojąć, że krytyk klasycyzujący i subtelny mógł widzieć w nich jedynie „zły smak i gminną przesadę”, z drugiej strony jednakże osąd ów zakwestionować można jako płynący z nazbyt wąskiego spojrzenia. Poświęcone uciechom podniebienia numery zajmują istotne miejsce w całokształcie przyjętej koncepcji dramatycznej, pozwalając na swój sposób ocieplić wizerunek monarchy i uwiarygodnić jego końcową przemianę, a także - po prostu - przyczynić się do czysto muzycznej efektowności spektaklu.

Trudno jednak przeoczyć fakt, że warszawska koncepcja sztuki istotnie kłóci się z wizją niemieckiego dramatopisarza, powściąliwszą, lecz konsekwentniejszą w formie, bardziej niepokojącą w wymowie i ostrzejszą w miejscami drastycznym, miejscami cynicznym, a generalnie subtelniejszym dowcipie, co przy pozostawieniu nietkniętej oryginalnej intrygi i dosłownym niemal tłumaczeniu mówionych dialogów skutkuje wewnętrznymi niespójnościami warszawskiej adaptacji. Nie pomylimy się chyba, widząc w tych niekonsekwencjach - wyraźnie wyczuwalnych pomiędzy niebanalną intrygą dramatu, ambitną szatą muzyczną i ewidentnym ludyzmem dodanych fragmentów - rękę Wojciecha Bogusławskiego i jego starań o dogodzenie rozmaitym gustom publiczności, która to przecież, jak pisał ojciec teatru polskiego we wstępie do lwowskiego Iskahara, jest „zbiorem wszelakich stanów, dostojności, oświecenia i powołania ludzi [...], wszyscy przeto mają prawo żądania zabawy w przedstawio-

52 T. 215-222 (s. I68 autografu partytury II aktu wg numeracji wprowadzonej w opisach skanów dostępnych na portalu Polona; zob. przyp. 27). 
nych sobie widowiskach. Krzywdziłby ogół, kto by jednej części społeczeństwa dogadzając, bawił ją wyłącznie tym, w czym inne mało albo wcale nie smakują"ş.

Obszarem zasługującym na oddzielną uwagę jest połowiczna skuteczność przeniesienia do utworu dramatycznych i muzycznych konwencji opery buffa/semiseria, które nie całkiem gładko - rzec by można - leżą na oryginalnie singspielowym dramacie Kotzebuego. Sztampowe operowe emploi rozdzielono pomiędzy postaci wedle klucza znanego z Uprowadzeniu z seraju, przyznając Husseinowi rolę primo basso buffo, choć to postać Wampuma - zgoła inaczej niż mozartowski basza Selim - pozostaje komicznym nerwem sztuki. Zastanawiać się wolno, czy lepszym nie okazałby się model znany z Axura - zarówno groźną, jak i groteskową rolę władcy w wiedeńskiej premierze opery Salieriego grał pierwszy basso buffo stolicy cesarstwa Frederico Benucci, w warszawskiej inscenizacji zaś specjalizujący się w tymże emploi Bogusławski. Rozmowy prowadzone przez Axura z Biscromą prezentują ewidentnie ten sam typ, co dialogi Wampuma z Husseinem.

Postać władcy u Salieriego i da Ponte pozostaje jednak raczej seria i niepozbawiona jest monarszej godności - artykułowanej również muzycznymi środkami - której Kotzebue Wampumowi odmówił. Z drugiej strony, umuzycznienie partii wschodniego despoty w poetyce typowej roli buffo caricato - nieodłącznie związanej z pierwiastkiem błazeństwa i dziedzictwem commedia dell'arte - byłoby praktycznie niewykonalne, nie tyle już ze względu na ewentualne - u Kotzebuego nieobecne - dostojeństwo monarchy, co nagi fakt stojącej za nim władzy. To napięcie pomiędzy śmiesznością głupca i żarłoka a grozą dzierżonej przez okrutnika władzy absolutnej decyduje o niepowtarzalności wykreowanej przez Kotzebuego postaci, która - rzec by można - z tego właśnie powodu w granicach ówczesnych konwencji operowych pozostaje „nieumuzycznialna”. Niepowtarzalna, choć igrająca z obiegowymi motywami i rozpowszechnionymi konwencjami koncepcja Kotzebuego okazuje się mocno osadzona w nadanym utworowi przez dramatopisarza kształcie gatunkowym.

$\mathrm{Z}$ tego punktu widzenia nie bez racji argumentować można, że sens końcowych scen warszawskiej adaptacji, wkładających w usta Wampuma nielicujące z pozycją władcy pastoralną arię czy też arietkę i komiczne duetto o pieczeni, leży nie tyle w ukazaniu moralnej przemiany despoty, co raczej w wodewilowym rozbiciu „,czwartej ściany”: obrócenie poważnej przecież, pomimo niebłahego pierwiastka komizmu, intrygi w farsę rozwiewa teatralne złudzenie, ukazując umowność przedstawionej rzeczywistości. Przejście do poetyki kończącego sztukę wodewilu, w którym aktorzy

[Wojciech Bogusławski], Dzieła dramatyczne Woyciecha Bogustawskiego, Warszawa I823, s. I. 
zwracają się wprost do publiczności, explicite sygnalizuje ostatni wers cytowanej strofy śpiewu Wampuma: „śpiewając, wszystko kończę”.

Można się zastanawiać, w jakim stopniu to właśnie niemuzykalność Wampuma uniemożliwiła pełną realizację potencjału stylu buffo, leżącego przecież w głównej mierze w możliwości muzycznego wyartykułowania akcji - szczególnie tej zasadzającej się na dialogowych interakcjach pomiędzy postaciami dramatu. Być może przyjęcie śpiewającej roli Wampuma poskutkowałoby pełniejszym udramatyzowaniem finału drugiego aktu poprzez wykorzystania sekcji ansamblowych o charakterze akcji czy też umieszczeniem tego rodzaju numerów także poza finałami. Nie przypadkiem chyba najbardziej efektowne tego typu fragmenty znalazły się tam, gdzie interakcja pomiędzy pozytywnymi i negatywnymi postaciami dramatu odbywa się bez udziału Wampuma.

Podejmując tego rodzaju dywagacje, pamiętać jednak warto, że produkcja Elsnera i Bogusławskiego, stojąca wpół drogi pomiędzy tradycyjnie rozumianym singspielem a pełnowymiarową operą buffa czy semiseria z dialogami mówionymi zamiast recytatywów secco, nie pozostaje bynajmniej na tle epoki odosobniona i wpisuje się dość dobrze w nurt wiedeńskich utworów niemieckojęzycznych tworzonych na podstawie starszych librett w ostatnich dekadach XVIII w. - na potrzeby National Singspiel i później. Opracowywane na nowo singspiele czy tłumaczone na niemiecki opera-comique często otrzymywały przy tej okazji wielosekcyjne finały - do utworów tego rodzaju należy przecież także Uprowadzenie z seraju, ze swoim jednym finałem buffo zamykającym akt drugis4.

W autobiografii Kotzebuego znaleźć można następujące wyznanie: „Spośród wszystkich moich sztuk Suttan Wampum najmniejsze miał powodzenie wśród publiczności; jest to, prawdę rzekłszy, mierny jeno utwór. Liczyłem na muzykę, przywykły widzieć nędzne wytwory Schickanderów, Vulpiusów i innych nader dobrze przyjmowane, gdy wsparte były geniuszem kompozytora"s5. Nie miał jednak Wampum szczęścia takich utworów Kotzebuego jak Spiegelritter, utrwalony w historii muzyki nazwiskiem Schuberta, czy Pustelnik z wyspy Formentera, odnoszący pokaźne sukcesy w muzycznym kształcie nadanym mu przez Ernsta Wilhelma Wolffa. Pierwszą muzykę do Wampuma skomponował Carl David Stegmann dla teatru w Moguncji

54 Zob.: Martin Nedbal, Morality and Viennese opera in the age of Mozart and Beethoven, London-New York 2017, s. 48-73, 208-209.

55 "Sultan Wampum ist unter allen meinen Stücken das Einzige, welches dem Publikum mißfallen hat. Es ist freilich nur ein sehr mittelmäßiges Produkt, ich rechnete dabey auf eine gute Musik, da ich gewohnt war, die jämmerlichsten Producte eines Schikaneder, eines Vulpius u. s. w., durch die Almosen der Tonkunst bereichert gut aufgenommen zu sehen", [August von Kotzebue], August von Kotzebue's Selbstbiographie, Wien I8II, s. II8. 
(I79I), później także Johann Andreas Amon (Heilbronn, I795), Franz Xaver Süßmayr (1795), Carl Ditters von Dittersdorf (pod zmienionym tytułem Schach von Schiras, Oleśnica, I795), Johann Heinrich Carl Bornhardt (Brunszwik, 1796), Joseph Ernst Ludwig Essiger (Lübben, 1797), Georg Feldmayr (1797), Frantisek Josef Benedikt Dusik (Lublana, 1797) a po Elsnerze także Josef Strauss (I832). Żadne jednak z tych dzieł nie wykroczyło poza efemeryczny żywot pisany większości ówczesnej produkcji operowej $^{56}$.

W dwóch przypadkach - choć tylko w jednym potwierdzonym muzycznym materiałem źródłowym - kompozytorzy, podobnie jak Elsner z Bogusławskim, ocenili libretto jako dające zbyt małe możliwości muzyczne. $Z$ doniesień prasowych wiemy, że gdy Stegmann wystawiał dzieło po raz drugi, w 1792 r. w Hamburgu, istotnie zmienił jego formę, dając mu - czy jak Elsner? - dwa „prawdziwie dramatyczne” finały57. Dittersdorf z kolei przekształcił singspiel Kotzebuego w regularną operę komiczną, zmieniając nieco intrygę, a przy tym dając Wampumowi, wbrew intencjom Kotzebuego, regularną rolę śpiewaną (bas) ${ }^{58}$. Trudno powiedzieć, czy i które opracowania mógł znać Elsner - gdy operę Dittersdorfa wystawiano w pałacu biskupim w Oleśnicy, Elsnera od czterech lat nie było we Wrocławiu ${ }^{59}$. Widział natomiast zapewne oryginał Wampuma wystawiany bez muzyki we Lwowie w roku $1797^{60}$.

W cytowanej już warszawskiej recenzji przeczytać można, że dziełko Kotzebuego „nie zyskało dotąd między własnymi jego ziomkami kompozytora, pana Elsnera bowiem po tyloletniej w teatrze naszym zasłudze, w poczecie [sic] krajowych muzyków policzyć możemy [...] Jeśli się w Niemczech jaki muzyk zajął tą kompozycją, może-

$56 \mathrm{~W}$ nawiasach podano rok i miejsce (jeśli jest znane) pierwszego (często jedynego) wystawienia. Dane zaczerpnięto z: Margaret Ross Griffel, Operas in German: A dictionary. Revised edition, t. I, Lanham 2018, s. 463; T. Bauman, op. cit., s. 405, a także z internetowego katalogu źródeł muzycznych RISM. Pokaźna liczba dzieł powstałych w 1. 1795-97 wynika z daty ukazania się druku libretta (Sultan Wampum, oder die Wünsche. Ein orientalisches Scherzspiel mit Gesang in drei Aufzügen, Lipsk 1794). O znaczeniu, jakie dla współczesnej muzykologii przedstawia większość tych produkcji, świadczyć może fakt, że w encyklopedii Die Musik in Geschichte und Gegenwart, w wykazie librett Kotzebuego zawartym w poświęconym mu haśle, przy Sultanie Wampumie zamieszczono jedynie nazwiska Stegmanna, Dittersdorfa i Straussa, zob.: Till Gerrit Weidelich, „Kotzebue, August Friedrich Ferdinand (von)” w: Die Musik in Geschichte und Gegenwart. Personenteil, red. Ludwig Finscher, t. Io, Kassel [etc.] 2003, s. 566-570.

57 T. Bauman, op. cit., s. 276. Muzyka Stegmanna nie zachowała się.

58 Ibid., s. 300. Więcej informacji o operze Dittersdorfa znaleźć można w katalogu Krebsa (Carl Krebs, Dittersdorfiana, Berlin I900, s. I23) i w opisie drezdeńskiego autografu opery zamieszczonym w katalogu RISM, gdzie znajduje się także częściowy indeks incipitów.

$59 \mathrm{Z}$ dużą dozą pewności przyjąć można, że powodzenie libretta Kotzebuego wśród kompozytorów operowych wynikało raczej z popularności dramatopisarza i dostępności drukowanego wydania dzieła, nie zaś z zetknięcia się z innymi opracowaniami, i że rzeczeni twórcy niekoniecznie świadomi byli działalności swoich poprzedników, por.: Peter Branscombe „Schubert and his librettists. I: Settings of existing librettos", The Musical Times II9 (1978), nr I629 (Schubert, Anniversary Issue), s. 944.

60 A. Nowak-Romanowicz, Klasycyzm, op. cit., s. I9I, przyp. 137. Tej realizacji dotyczy zapewne nieścisła informacja podawana przez Jerzego Gota, że we Lwowie wystawiano niemieckiego Wampuma z muzyką Elsnera, zob.: J. Got, op. cit., s. 399. 
my wnosić, że dzieło jego bardzo mało zyskało wziętości” ${ }^{61}$. Rozdźwięku pomiędzy pierwszym stwierdzeniem a podaną wyżej obszerną listą kompozytorów nie trzeba tłumaczyć brakiem orientacji recenzenta - zastrzeżenie zawarte w drugim zdaniu zacytowanego fragmentu wydaje się wystarczające, zważywszy, co o powodzeniu libretta pisał sam Kotzebue. „Szczęśliwszym był pan Elsner - czytamy dalej - bo dzieło to, choć od piętnastu lat w Warszawie znane, dość licznych zawsze przywabia słuchaczów”. Okoliczności te nie dają zbyt mocnej podstawy do porównywania wartości samych utworów, zwłaszcza że powodzenie spektaklu lub jego brak zależało od tylu innych czynników, z muzycznymi i teatralnymi siłami wykonawczymi na czele ${ }^{62}$, niemniej fakt pozostaje faktem - to właśnie warszawska adaptacja, oparta na muzyce Elsnera, której przyznano tu rolę ważniejszą i bardziej substancjalną niż przewidywało to oryginalne libretto, spełniła nadzieje dramatopisarza, o których pisał w cytowanym fragmencie autobiografii. Nawet nie pochwalając upodobań znacznej, jak się wydaje, części ówczesnej publiczności warszawskiej i podzielając opinię cytowanego recenzenta o „złym smaku i gminnej przesadzie” ujawniających się w „gastronomicznych" numerach opery, przyznać trzeba, że dzieło Elsnera - zarówno jako konstrukcja dramaturgiczna, jak i w swoich czysto muzycznych walorach - stanowi kompozycję dość udaną, przy tym zaś przynosi z sobą jedyne bodajże w polskiej twórczości operowej przykłady numerów utrzymanych w czystym stylu wiedeńskiej opery buffa ostatnich dekad XVIII w. - dwie arie basowe i kwartet z początku finału I aktu. Kosztem dokonanej transformacji gatunkowej było jednak częściowe zatarcie oryginalnej, spójnej i niebanalnej koncepcji niemieckiego dramatopisarza. Ten fakt uwidacznia się tym bardziej jaskrawo, że szczątkowy, pozbawiony mówionych dialogów kształt, w jakim dotrwała do naszych czasów warszawska adaptacja singspielu Kotzebuego, skazuje ją niejako na ciągłą konfrontację z niemieckim oryginałem ${ }^{63}$.

6I Recenzje teatralne towarzystwa Iksów, op. cit., s. 29.

62 Choć, biorąc za punkt odniesienia poziom innych europejskich stolic, nie można prawdopodobnie powiedzieć zbyt wiele dobrego o generalnym poziomie muzyków teatru warszawskiego z pierwszych dekad XIX w., sztuka aktorska stała na poziomie dość wysokim, a czołowi artyści nie ustępowali aktorom najlepszych scen europejskich, zob.: S. Durski, Ludwik Adam Dmuszewski, op. cit., s. 74-77. Największym atutem warszawskiej adaptacji była tytułowa rola Żółkowskiego (por. cyt. recenzja, s. 30). Co ciekawe, z przywoływanej wielokrotnie w toku artykułu recenzji zdaje się wynikać, że spektakl nie wykorzystywał w pełni potencjału tkwiącego w „nadprzyrodzonych” efektach sztuki, w zakresie scenografii, kostiumów i maszynerii teatralnych.

63 Nie należałoby chyba wzdragać się przed uzupełnieniem polskiego libretta o nowy przekład niezachowanych partii mówionych, gdyby pojawiła się możliwość współczesnego wystawienia opery. Oryginał Kotzebuego nie zawiera literackich subtelności mogących budzić respekt, a zachowane fragmenty tłumaczenia Bogusławskiego i Glińskiego nie stawiają zbyt wysokich wymagań. Naturalna różnica pomiędzy słowem wierszowanym (zachowanym w numerach muzycznych) a prozą (niezachowanych dialogów mówionych) usprawiedliwiałaby nawet w jakimś stopniu współczesny przekład tej ostatniej rezygnujący z elementów historycznej stylizacji językowej. 
'BAD TASTE AND COMMON EXAGGERATION'. SEVERAL REMARKS ON THE MUSICAL AND DRAMATIC STRUCTURE OF JÓZEF ELSNER'S OPERA SULTAN WAMPUM, AS COMPARED WITH THE ORIGINAL LIBRETTO BY AUGUST VON KOTZEBUE

The paper discusses Józef Elsner's opera Sultan Wampum with texts by Wojciech Bogusławski and Augustyn Gliński, analysed here as an adaptation of the German libretto by August von Kotzebue. I have questioned the Warsaw reviewer's opinion of I8Is (quoted in the title), in which he criticised the Polish translators for inserting 'common' and unnecessary elements in the text. Instead, I present those added sections as a result of Elsner and Bogusławski's consistent concept for the adaptation of Kotzebue's peculiar type of singspiel and transforming it into a fully-fledged comic opera. The additions thus mainly stemmed from the consideration of musical-dramatic form and their choice of genre. I examine changes in the structures of acts, and the character of the added solo numbers. I also discuss in detail the extensive finales, which are the main point at which the Warsaw authors interfered with the original libretto. The changes they introduced distorted the coherent vision of the German librettist and led to internal discrepancies in the Warsaw version, which, nevertheless, proved to be a successful adaptation of the work to the tastes of the wide audience that frequented Warsaw's theatres.

Translated by Tomasz Zymer

Słowa kluczowe / keywords: Józef Elsner, August von Kotzebue, Suttan Wampum, opera, singspiel.

Jakub Chachulski, uzyskał doktorat w dziedzinie sztuki na Uniwersytecie Muzycznym Fryderyka Chopina w 2014 r., jest autorem publikacji poświęconych problemom estetyki muzycznej i zagadnieniom teoretycznym związanym $\mathrm{z}$ wykonawstwem muzyki dawnej, także tłumaczem i redaktorem polskiej edycji dzienników muzycznych podróży Charlesa Burneya (20I7 i 2018 r.). Od 2016 r. współpracuje z Instytutem Sztuki PAN przy pracach w ramach serii Monumenta Musicae in Polonia, od 2018 r. jako pracownik tejże placówki. Aktualnie finalizuje część katalogu tematycznego utworów J. Elsnera obejmującą całość jego świeckiej twórczości. q_ba@vp.pl 